\title{
Dansk spejderarbejde i Aabenraa 1919-34 - et led i genforeningsprocessen
}

\author{
Af Erik Jessen
}

I 1919 slog den danske spejderbevægelse rod i Sønderjylland. Også Aabenraa fik aktive spejdere. Arbejdet blev stærkt præget af det lokale miljø. De lokale ledere lagde vægt på, at spejderne havde en særlig opgave at udføre $i$ dansk-national sammenhæng. De egentlige spejderfærdigheder trådte mere i baggrunden. Dette skabte i 1920'erne modsætninger til Det Danske Spejderkorps, som hævdede spejderbevægelsens internationale karakter, og det gjorde balancegangen over for de tyske spejdere vanskelig.

Fhv. amtsborgmester Erik Jessen, selv gammel Aabenraa-spejder, trækker modsætningerne frem og tegner et billede af Aabenraa-spejdernes aktiviteter.

I 1919 havde Det Danske Spejderkorps i Danmark trådt sine børnesko, var blevet ti år gammelt og talte 4.300 spejdere fordelt på 150 troppe landet over.

Det var naturligt, at dansk spejderarbejde påkaldte sig interesse i Senderjylland, da genforeningen stod for døren. I løbet af året 1919 oprettedes spejdertroppe i de fire købstæder, Haderslev, Sønderborg, Tønder og Aabenraa samt i Flensborg. Der foreligger også oplysninger om et begyndende spejderarbejde i en række mindre byer. Nævnes kan Graasten, Broager, Varnæs, Bovrup, Felsted, Rødekro, Bolderslev, Christiansfeld, Fjelstrup og Gram ${ }^{1}$. De fleste af disse troppe og patruljer ${ }^{2}$ fik kun kort levetid, men senere dukkede et mere vedvarende spejderarbejde op i mange mindre bysamfund.

Det første initiativ synes at være taget i Tønder, hvor 28 drenge den 29. april 1919 mødtes hos gæstgiver Schmidt i Vestergade og oprettede en trop under ledelse af Lauritz Westergaard ${ }^{3}$. I Sønderborg mødtes de første spejdere den 10. juni på Sønderborghus, hvor »delegerede fra Det Danske Spejderkorps« holdt møde, formentlig for at forberede korpsets besøg på Dybbøl i juli samme år. Omkring samme tid påbegyndtes et spejderarbejde i Haderslev under ledelse af Vald. Møller, journalist Søkjær og sagførerfuldmægtig P.A. Madvig. I Flensborg er spejderarbejdets officielle fødselsdag den 10. august 1919, men "da var der allerede sket adskilligt. Gamle Ravn havde deltaget $i$ Fredericiaspejdernes sommerlejr på Treldenæs. « Gamle Ravns borgerlige navn var Svend Johannsen ${ }^{4}$. Han blev senere en markant skikkelse i det danske skole- og spejderarbejde i Sydslesvig. 
Lejren på Treldenæs var en KFUM-spejderlejr, af hvilken grund de første flensborgske drengespejdere bar KFUM-spejdernes grønne uniformer i modsætning til de nordslesvigske drengespejdere, der var tilknyttet Det Danske Spejderkorps og bar khakifarvede. Spejderarbejdet i Sydslesvig kom senere til at omfatte også andre byer end Flensborg og har til i dag været en vigtig faktor i dansk børne- og ungdomsarbejde dér. I alle årene fandtes også et korps bestående af piger. De to korps sammensluttedes i 1972 til ét under navnet Dansk Spejderkorps Sydslesvig og bærer i dag blå uniformer med gule tørklæder; de slesvigske farver.

\section{Aabenraa-spejdernes første år}

I Aabenraa mødtes en aften i foråret 1919 på Folkehjem en del drenge med tropsassistent fra 2. Hellerup trop, Hein Johansen. Han var af Det Danske Spejderkorps sendt til Sønderjylland for at invitere sønderjyske drenge til at deltage i korpsets lejr ved Hindsgavl i juli 1919. Hein Johansen, Jonas som han kaldtes, var indbyder til de begyndende møder i Aabenraa og Sønderborg og har muligvis også taget andre initiativer. Efterfølgende bosatte han sig $i$ Sønderborg, hvor han optog en lærergerning.

Mødet på Folkehjem var ikke den første spejdersammenkomst i Aabenraa. Der foreligger beretninger ${ }^{5}$ om eksistensen af et spejderarbejde allerede i 1918. Disse første spejdere i Aabenraa fik stillet et skovareal til rådighed som lejrplads af gårdejer Jacob Michelsen i Kolstrup. Det viste sig imidlertid at være så fugtigt, at man måtte dræne det. Formentlig blev arealet aldrig anvendt som egentlig lejrplads.

Mødet på Folkehjem satte imidlertid gang $\mathrm{i}$ arbejdet, og femten Aabenraadrenge inviteredes til at deltage i korpslejren ved Hindsgavl samme sommer. Herom foreligger en beretning, skrevet i 1925 af en af deltagerne, Arthur Jørgensen':

"Den 15. juli samledes de udtagne 15 spejdere fra Aabenraa med holdene fra de øvrige sønderjyske byer i Haderslev. Der var sørget for privat indkvartering. Næste morgen tog vi med toget til Christiansfeld. Herfra marcherede vi over grænsen til Taps, derfra videre med toget. Klokken 4 ankom vi til lejrpladsen, som lignede en stor teltby. Alt arbejde blev nedlagt, da vi rykkede ind på pladsen. Ikke så underligt, da vi var i civil påklædning og var udrustede med kufferter. Enkelte skolekasketter med deres iøjnefaldende farver sås hist og her. Truppen blev overgivet til herr 
Jacob Jacobsen (19012-75), farvermester i Aabenraa, var formentlig den forste Aahenraa-dreng. der blev dansk spejder, idet han blev spejder, medens han var i lare $i$ Odense. Her ses han som 15-arig $i$ januar 1916 med băde signalhorn og spejderstav. Torklede anvendtes uhenhart ikke så tidligt. Jacoh Jacohsen var en af igangscetterne af spejderarbejdet i Aabenraa og forer en tid, men matte opgive det, da han indkaldtes til militartjeneste.

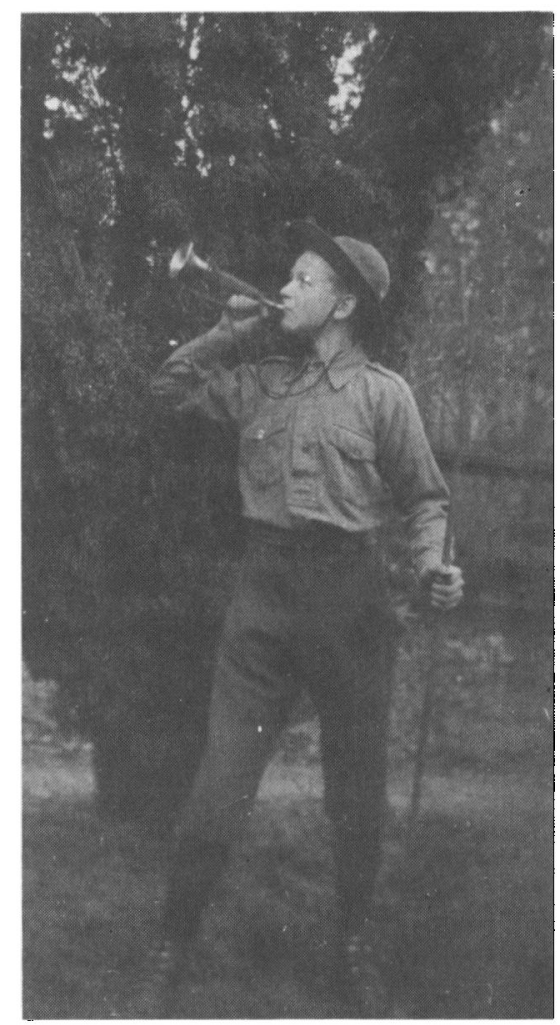

rektor Hartvig-Møller, som skulle være vores fører ${ }^{7}$. Teltene blev hurtigt slået op, alt imens den ene trop efter den anden under hornmusik ankom til lejren. Hermed begyndte lejrlivet. Snart var vi vant til at lave havregrød, der ikke var sveden. Efter reveillen gik det i fuld fart ned til badestranden under råbet: "Sønderjyder, Sønderjyder, hæp,hæp,hæp.« Efter et par dages forløb var negleparaden heller ikke mere nødvendig. Anden dags aften blev uniform, benklæder og strømper udleveret. Jeg var "så heldig“ at få nogle strømper, som var så fuldkomne, at begge ben kunne være $i$ én strømpe. Under rektor Hartvig Møllers ledelse nåede vi alle at blive færdige med rekrutprøven ${ }^{8}$ den 20 . juli. Den 23. juli sejlede tre dampere med den 1400 mand store spejderhær til Sønderborg. Flere tusinde mennesker havde ved ankomsten givet møde ved havnen. Byen var flagsmykket for første gang under Dannebrog. Der blev slået lejr for natten i Dybbøl skanser. Den næste dag 


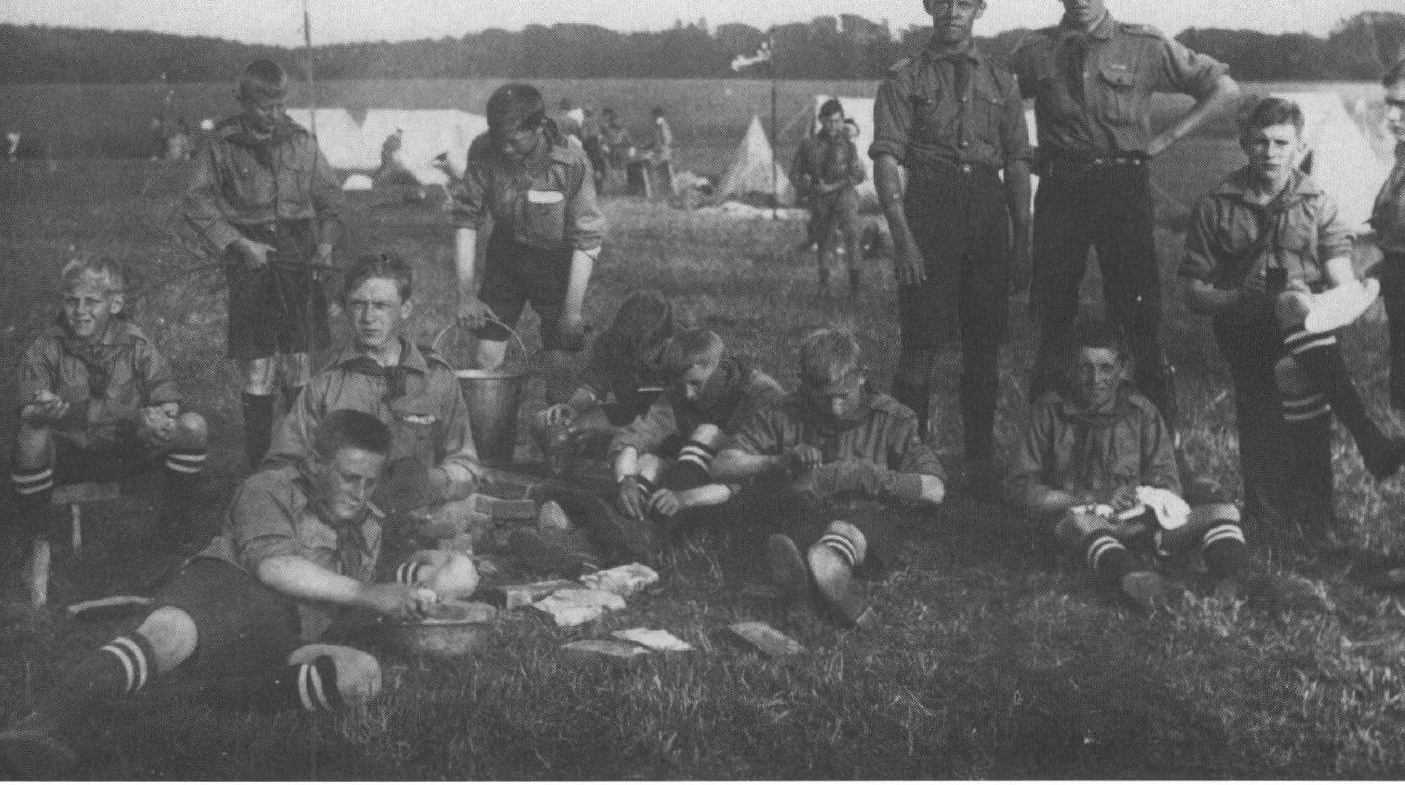

Aabenraa-spejdere i Hindsgavl-lejren 1919.

Stäende fra venstre: Arthur Jorgensen, Johan Nissen (Rise), to Hellerup-spejdere og yderst til hojre: Anton Salomonsen. Siddende fra venstre: Ejner Husmann, Jacob Jacobsen, Andreas Hansen (Felsted). Hans Danielsen, Hans Jendresen. Johan Poulsen (Lojt) og på trablok: Jürgen Andresen. Liggende foran til venstre: Svend Wilgaard. De ovrige deltagere i lejren var: Holger Jorgensen, Gustav Johannsen, Lorenz J. Hansen og Frederik Kraft.

blev benyttet til at bese Dybbøl mølle, krigergravene og Broager. En stor skare mennesker havde ligeledes indfundet sig, da vi om eftermiddagen sejlede bort. Den 25. juli blev 53 sønderjyske rekrutter udnævnt til 2. klasses spejdere'. Samme dag fik hver trop overrakt en fane af Danmarkssamfundet. Vor fane fik vi uden vanskeligheder med over grænsen. Den 26. juli blev lejren brudt op, og spejderne tog hjem. Aabenraa-holdet var ledet af Gustav Johannsen og Jacob Jacobsen, der begge som de første førere gjorde et stort arbejde for at fremme spejderbevægelsen $i$ vor by."

At de nye sønderjyske spejdere var velkomne gaster $\mathrm{i}$ lejren ses af, at de blev tilknyttet Hellerup Division ${ }^{10}$, der var under ledelse af rektor Hans HartvigMøller, Gl. Hellerup Gymnasium. Det var her dansk spejderarbejde begyndte i 1909. Hartvig Møller, der var kendt som en fremsynet pædagog, var i de første årtier en meget aktiv spejderfører, der ikke skånede sig selv, og som siden nøje fulgte arbejdet. 



den danske, men uden om den tyske til harme for tyskerne. På afstemningsdagen hjalp vi til med at befordre gamle og svage folk til og fra afstemningslokalerne. Om aftenen bragte vi resultaterne til de forskellige samlingssteder.«

En af de pressemænd ${ }^{12}$, der opholdt sig i Aabenraa i afstemningstiden, har set begivenhederne sådan:

"Blandt dem, der bør have deres eget kapitel, når der engang skal fortalles om afstemningsforberedelserne, er spejderne. Hvad de små spejdere, såvel drenge- som pigespejdere udrettede, var simpelthen fænomenalt. De har gjort deres store indsats for danskheden i de nordslesvigske købstæder. Fra tidlig morgen til silde aften og i al slags vejr var de på færde. Hurtige, pålidelige, sikre i alt hvad de påtog sig. Og det var meget. De udførte altid en tjeneste, som det var vanskeligt at få voksen hjælp til, og hvad mere er, gjorde ofte mands og kvindes arbejde med i valg- og indkvarteringsbureauer. Altid på færde, altid hjælpsom over for alle - og med en mærkelig korrekt og taktfuld opfattelse af, hvad de bør gøre eller ikke.«

Ved en fest på Folkehjem $\mathrm{i}$ april fik alle spejdere overrakt en erindringsmedalje, der på initiativ af købmand Hans Michelsen ${ }^{13}$ var indstiftet af en kreds af byens borgere. I det hele taget blev 1920 et meget travlt år for de nye spejdere. I alt kan tælles 32 større arrangementer, deraf 13 søndags- eller weekendture foruden deltagelse i genforeningsfesten på Dybbøl, og kongemodtagelse i Aabenraa. Om sommeren deltog nogle af spejderne $i$ en lejr ved Halk. Den var arrangeret af Hellerup Division, som de kendte godt fra Hindsgavllejren. Lejren blev ledet af lektor Klavs Vedel ${ }^{14}$, der $\mathrm{i}$ indbydelsen skriver: "Der vil blive lejlighed til uddannelse af uøvede spejdere«. Lejren må således opfattes som en håndsrækning til de nye spejdere i Sønderjylland. Hartvig Møller sender forud for lejren et postkort, hvorpå han meddeler: "Vi har fået 1000 kr. foræret, derfor kan der søges om tilskud på $15 \mathrm{kr}$. per deltager og enkelte fripladser.« At økonomien kunne være et problem ses af en samtidig meddelelse fra tropsassistent Hans Otto Jendresen ${ }^{15}$. Felsted, der meddeler, at man ikke kan deltage i lejren. "Det er for dyrt."

Som det fremgår af det foregående, var det allerede til afstemningsdagen lykkedes at få stablet et signalhornsorkester på benene. Det har givet blod på tanden, for kort efter besluttede man at etablere et egentligt hornorkester. De første instrumenter indkøbtes i København, hvorfra de, sammen med 50 


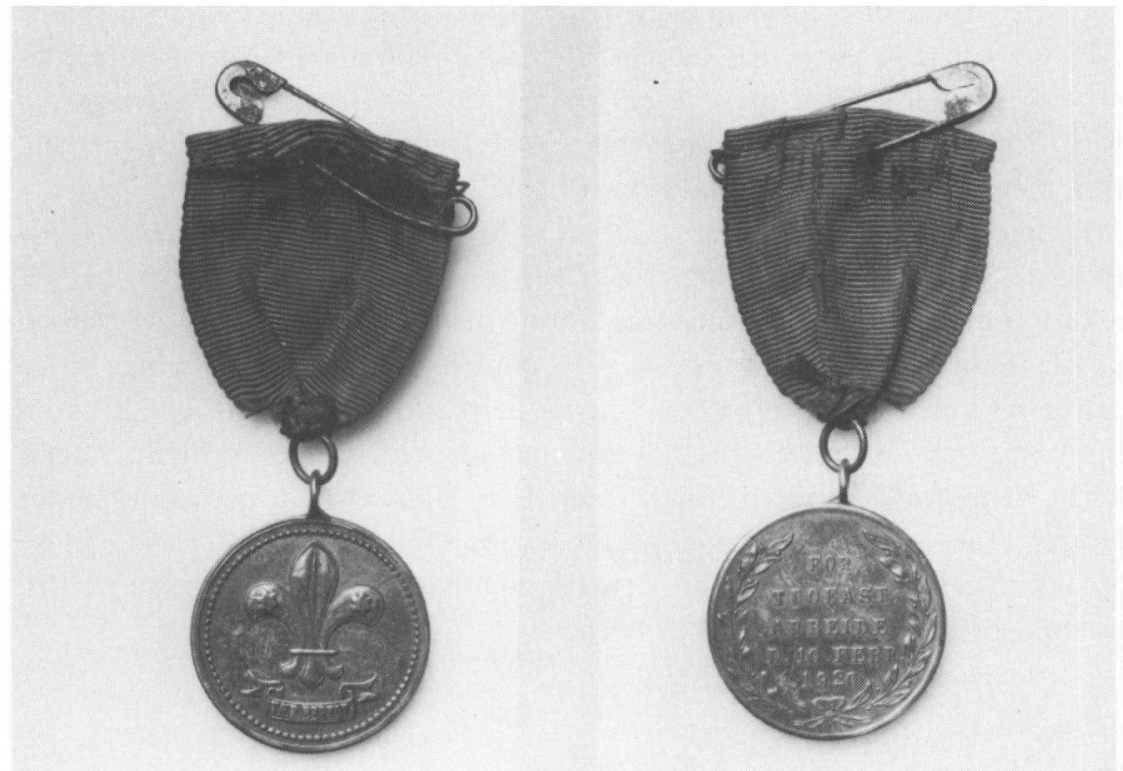

Som anerkendelse af det arbejde, drenge- og pigespejdere udforte ved afstemningen, indstiftede en kreds af byens borgere en medalje, der overraktes alle medvirkende spejdere. Medaljen er med blåt bånd og viser på den ene side en spejderlilje, medens indskriften på den anden side lyder: For trofast arbejde $d$. 10. febr. 1920. Den afbildede medalje har tilhort mekaniker Nis Schmidt.

spejderuniformer fra Spejdernes Munderings Depot, blev sendt til grænsen, hvor der måtte betales kr. 20,65 i told for instrumenterne. For at få uniformerne leveret måtte tre af byens respekterede borgere, farvermester Thorkild Jacob$\operatorname{sen}^{16}$, dr. med. Carl Meyer og redaktionssekretær Harald Rud ${ }^{17}$, afgive "selvskyldnerkaution in solidum og med betaling 1 . juli senest, uafhængig af datoen for Genforeningen«. Også en kolonnestander indkøbtes, en grøn dug med byens våben, de tre makreller, indbroderet. På standeren sattes en stor sølvplade med teksten "Aabenraa Spejderkorps 10.2.1920«. I 1924 kom der dertil endnu en sølvplade med "Mor Danmark «, den danske kvinde med Dannebrog. Var det besværligt at få leveret det nødvendige udstyr, kneb det også med pengene. Den 5. juli sender Georg Olsen, som havde taget initiativet til hornorkestret, således et afdrag til Spejdernes Munderings Depot i København, men må samtidig beklage, at han ikke kan sende flere. "Vi mangler kroner, det er sønderjydernes valgsprog, hvad der er fuldstændig rigtigt«, skriver han, men bestiller dog samtidig nogle røde duske til spejderhatten, insignierne for en tropsassistent. Men senere på året må depotet henvende sig til kautionisterne, 
hvorefter restbeløbet formentlig er blevet betalt. Man lå dog ikke på den lade side og søgte at skaffe penge. I august 1920 søger kolonnen således politimesteren om tilladelse til at afholde en spejderfest på Kramers Gæstgivergård i Rise - til kl. 2 nat. "Penge er nødvendige«, skriver Georg Olsen i ansøgningen. Den blev bevilget, omend kun til kl. 1 .

I januar 1921 afløstes Georg Olsen som kolonnechef af adjunkt Viggo Rosent. Samtidig hermed valgtes også et forældreråd for kolonnen, der fik rektor Ingvar Mogensen, Aabenraa Statsskole, som formand. At Mogensen knyttedes til arbejdet skulle vise sig at få stor betydning. idet rektor blev uhyre engageret $i$ arbejdet og ofrede megen tid derpå, foruden at han udadtil kom til at stå som en slags garant. Til kolonnerådets første næstformand valgtes ingen ringere end sønderjydernes fører, H.P. Hanssen. Da også borgmester Holger Fink og farvermester Thorkild Jacobsen blev medlemmer af rådet og redaktionssekretær Harald Rud kasserer, må man sige, at spejderarbejdet fra forste færd placerede sig stærkt $i$ byen.

\section{Kongeå Divisionen}

I januar 1921 indkaldte Rosent, efter opfordring af spejderchefen Cay Lembcke, til et møde for at oprette en syd- og sønderjysk division. Det var Lembckes ønske, at divisionen blev "grænseoverskridende«. I mødet, der fandt sted i Haderslev, deltog derfor repræsentanter fra Aabenraa, Felsted, Rødekro, Haderslev, Christiansfeld, Fjelstrup, Gram, Kolding, Fredericia og Vejle. Fra Aabenraa deltog dommer Andersen, dr. med. Carl Meyer, købmand Hans Michelsen og redaktionssekretær Harald Rud.

Divisionen blev dannet, men man nåede på dette første møde kun at drøfte organisatoriske forhold og at vælge divisionschef, hvilken opgave Rosent påtog sig. Fastlæggelse af budget og kontingent overlodes til den nyvalgte adjudant, Kay Petersen, der klogeligt fastsatte kontingentet til samme niveau som på Fyn.

På det tidspunkt eksisterede der en sydvestjysk division omfattende Ribe Amt, og der var allerede oprettet en grænsedivision på initiativ af Jonas. Den strakte sig fra Sønderborg til Tønder. Den nye division fik amtsskolekonsulent N.J. Nielsen, Sønderborg, og kaptajn A. Malling Jacobsen ${ }^{18}$ som chefer. Nielsen havde tidligere været spejderfører i Hellerup.

Rosent meldte allerede i 1922 fra som divisionschef, han var »nået til bunden af sine private midler«. Divisionens ledelse blev overdraget forstassistent Jens Hvass, Ulvshus ved Haderslev, og dermed fik divisionen en chef, der samtidig var aktivt med i korpsets ledelse. Men det varede kun kort, allerede året efter 


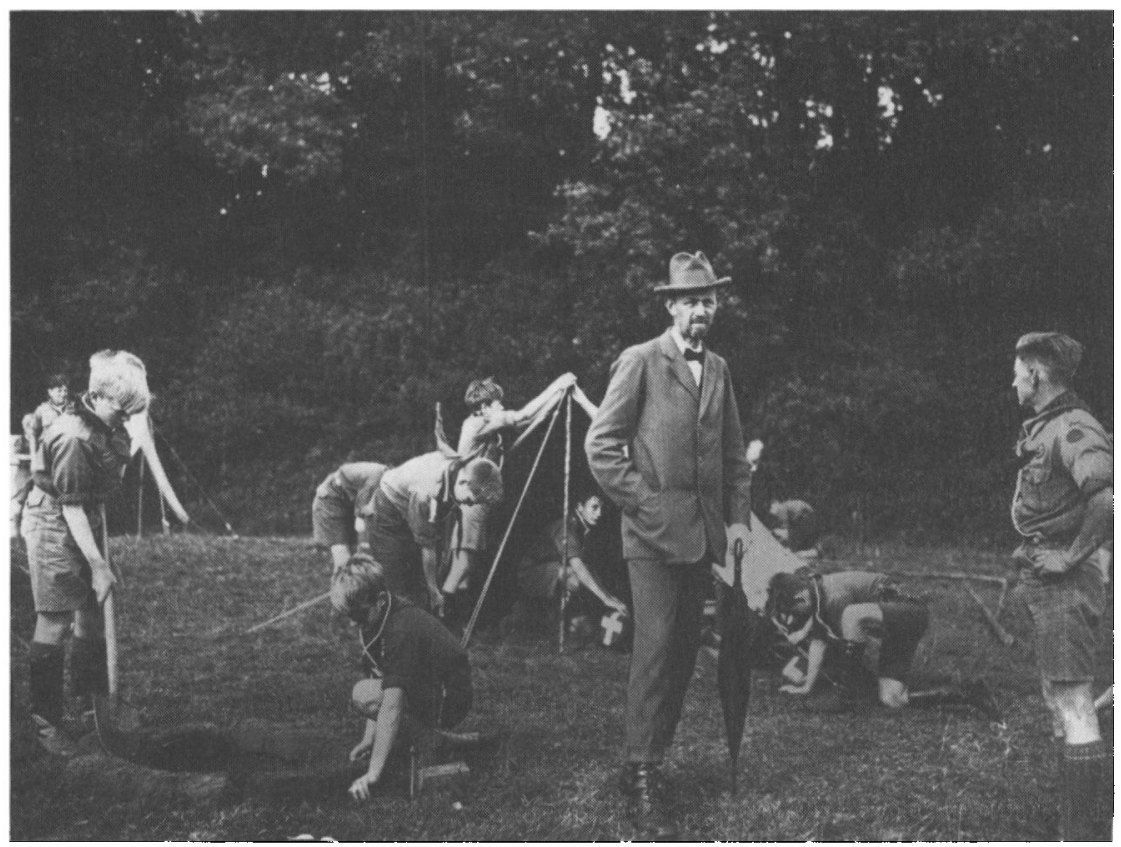

Et karakteristisk billede af rektor Mogensen, Aahenraa, som han fardedes blandt usine spejdere«, her i 1929 ved en kolonneturnering. Ingvar Mogensen (1871-1954) var fodt i Kobenhavn, cund.theol. og candmag. Som studerende medlem af Akademisk Skyttekorps og den sonderjyske studenterforening To Lover. Rektor, Aabenraa Statsskole 1920-41. Som formand for kolonneradet fik han stor indflydelse på spejderarhejdet, der optog ham overordentligt meget. Han folte det wsom en lykke at vare ungdomsopdrager og tog med stor glade fat pă opgaven med at opdrage sonderjysk ungdom" (Statsskolens Elevskrift 1947).

flyttede Hvass til Sjælland. I 1922 sammensluttedes de to divisioner, og kort efter lykkedes det også at få den sydvestjyske division med, således at Kongeå divisionen herefter omfattede området fra grænsen til en linie nord om Varde/ Vejle. Madvig ledede divisionen indtil 1936 bortset fra et halvt års tid i 1932, da cand. jur. William Nielsen ${ }^{19}$ var divisionschef. Fra 1936 overtog lektor Kai Krebs, Ribe chefposten.

\section{Hverdag og fest 1920'erne}

Efter at være afløst som divisionschef i 1921 kunne Rosent nu koncentrere sig om hvervet som chef for Aabenraa kolonne. Det daglige arbejde her kan følges gennem referater fra førermøderne, protokollerne og gennem eksisterende 
dagbøger fra troppe og patruljer. Som en rød tråd gennem de mange optegnelser mærker man de lokale dansk-nationale opgaver. På førermøderne er det almindeligvis daglige ting, der drøftes, f.eks. kontingent og planer for møder og ture. På det første møde (21. januar 1921) udnævnes en del ordonnanser ${ }^{20}$. Deres opgave var at stå til rådighed for kolonnechefen. Orkestret var under udvikling. I samme møde besluttes det at indkøbe stortromme og bækken. Prisen anslås til 10.000 mark, så det må antages, at indkøbet er foretaget syd for grænsen for at drage fordel af den ekstremt lave kurs på den tyske mark.

I april 1921 fik Aabenraa spejderne fint besøg, idet spejderchefen, Cay Lembcke aflagde byen besøg. Efter parade, møder og en festbanket på Hotel Royal fulgtes Lembcke med et stort fakkeltog til banegården, hvilket gav anledning til nogen kritik, idet nogle ældre borgere mente, at et fakkeltog burde være forbeholdt kongen. Året efter deltes det Danske Spejderkorps i øvrigt $\mathrm{i}$ to korps, idet omkring halvdelen af troppene, som protest mod Lembckes ledelse, trak sig ud og dannede Spejderforbundet. De sønderjyske afdelinger forblev i korpset. Efter at Lembcke i 1923 blev tvunget til at forlade spejderchefposten på grund af planer om et spejderarbejde med et vist militært og politisk indhold, sammensluttedes de to korps igen, nu under ledelse af civilingeniør Ove Holm, der var korpsets førstemand helt indtil 1960 og således fik afgørende indflydelse på korpsets udvikling i disse mange år.

Den 4. marts 1923 får kolonnen besøg af divisionschef Jens Hvass, der sammen med P.A. Madvig holder møde med Rosent og de to førere, Arthur Jørgensen ${ }^{21}$ og Peter Tiedemann ${ }^{22}$. Man drøfter den forestående divisionsturnering og orkestrets virksomhed. Om det sidste noterer Hvass i sin dagbog: »Det er skandaløst. 13 mand, der kun musicerer .... Man har mange penge i kassen, måske $1000 \mathrm{kr}$. Folk nægter at støtte, fordi spejderne ikke marcherer nok gennem gaden med musik og faner!!! Lovede at komme snart derned."

Disse kritiske bemærkninger om orkestret skyldes, at Jens Hvass ikke accepterede orkestervirksomhed som et led i spejderarbejdet. I det hele opfattede han, ikke uberettiget, spejderarbejdet i Aabenraa mere som et nationalt drengearbejde end et egentligt spejderarbejde, der lagde vægt på spejderfærdigheder, frilufts- og lejrliv. Disse modsætninger kom til at præge Aabenraa Kolonnes forhold til korpset helt frem til omkring 1930.

Ved et førermøde i september 1924 drøfter Rosent en ændret udformning af spejderløftet ${ }^{23}$ med sine førere. Der bliver enighed om, i sætningen, hvor der tales om troskab mod Gud, Konge og Fædreland, at foreslå ordet konge streget. Pudsigt nok gennemgår man ved selvsamme møde også programmet for kolonnens markering af kongens fødselsdag (26. september). Man begynder med en march gennem byen om morgenen kl. 6.30. Om aftenen er der fakkeltog med udgangspunkt på Storetorv. Samme år arrangerer kolonnen for første 
gang en juleindsamling. Spejderne med orkester og en julemand i spidsen marcherer gennem byen til Storetorv, hvor kolonnen har rejst et stort juletræ. Her musicerer orkestret, mens spejderne med raslebøsser samler ind, og julemanden snakker med børn og voksne og modtager ønskesedler. Det indkomne beløb, kr. 155,75, blev afleveret til Kogeforeningen. Dette julearrangement blev en årelang tradition.

Under fælles øvelse med andre spejdere havde det vist sig, at Aabenraaspejderne var sikre vindere, når det gjaldt terrænøvelser, hvor det ofte var vigtigt at have fysisk styrke. Knap så godt stod det til, når man mødtes med andre til kappestrid i almindelige spejderfærdigheder. Efter en divisionsturnering $\mathrm{i}$ 1926 i Ribe aflagde divisionschef Madvig et besøg hos Rosent, der havde kritiseret turnering og dommere. Om besøget noterer Rosent: "Madvig havde ikke været tilfreds med dommerne og måtte give Rosent ret $\mathrm{i}$ adskillige punkter, ligesom han mente, at turneringen ikke egentlig var egnet til at fremme det kammeratlige forhold inden for divisionen. Rosent understregede, at kolonnen efter hans opfattelse ikke var blevet loyalt behandlet, ligesom han mente, at målene var sat for højt.«

Madvigs besøg har dog ikke tilfredsstillet Aabenraaførerne. Et par måneder efter inviterer divisionen til en større terrænleg ved Vejen. Rosent mener da, at kolonnen bør sige nej. "Kolonnen har været nok til grin for divisionen", noterer han, der også finder, at det er mere rigtigt at blive hjemme på kongens fødselsdag (26/9). Resultatet blev et større kongefødselsdagsarrangement $\mathrm{i}$ Aabenraa med afslutning på statsskolen efter indbydelse af rektor.

I marts 1926 drager kolonnen med orkesteret i spidsen til Flensborg, hvor der efter indbydelse fra Flensborg spejderne er privat indkvartering, festaften i Duborg-Skolens festsal og søndag eftermiddag en sammenkomst i Borgerforeningen. Forud herfor marcherede spejderne til den gamle kirkegård. Det sker uden fane. Det var forbudt at fremføre Dannebrog offentligt. Der deltog 42 spejdere fra Aabenraa. Der følger straks en geninvitation til en fælles weekend, men det ses ikke, om den blev imødekommet. En senere indbydelse fra Flensborg må kolonnen sige nej tak til. "Vi har nok at se til«, lyder afslaget. Men det betød ikke, at kontakten var afbrudt. Senere fulgte adskillige fællesture.

Mod slutningen af 1926 meddeler Rosent, at han ønsker at ophøre med at være kolonnechef, men gerne fortsat er til rådighed for førerne og interesseret i protokollen og kartoteket. Kriminalbetjent, løjtnant F. Simonsen påtager sig jobbet som ny kolonnechef. Inden Rosent fratræder, påbegynder man dog forberedelserne til den divisionsturnering, der $\mathbf{i}$ foråret 1927 skal finde sted $\mathbf{i}$ Aabenraa, formentlig et resultat af den fra Aabenraa rejste kritik af den foregående turnering. Man drøftede også muligheden af køb eller byggeri af en hytte til spejderbrug. "En bydende nødvendighed «, noteres der. Efter sin 
kongerigske hjem, dog med et stærkt islæt af sidstnævnte. I 1927 var ca. 56 drenge sønderjyder og ca. 25 rigsdanske. Kolonne- og tropsråd var meget præget af folk nordfra, ligesom de tre første kolonnechefer var rigsdanske. Derimod var alle tropsførere stort set sønderjyder og folk uden nogen højere uddannelse. Den store interesse for spejderarbejdet hos folk nordfra er sikkert udtryk for, at man fandt, at det var godt for børnene at være med i et aktivt dansk ungdomsarbejde, men det har sikkert også haft betydning, at mange følte sig kaldet til at virke for fremme af det danske arbejde.

Den nye kolonnechef, kriminalbetjent, tidligere løjtnant, Frederik Simonsen tog med stor energi fat på sit nye job. Han havde ingen forudgående spejdererfaring. Et par år senere noterede han i dagbogen: »Med bange anelser gik jeg min spejderfremtid i møde, men med glæde over udsigten til at kunne tage aktiv del $\mathrm{i}$ ungdomsarbejdet blandt den danske ungdom $\mathrm{i}$ grænseegnen tog jeg fat."

Chefskiftet markeredes ved en storstilet parade på Statsskolens plads den 27. februar 1927, hvor Aabenraa-spejdernes nye chef aflagde spejderløftet foran fronten. Om aftenen var der fest på Folkehjem. Kolonnen omfattede da de to troppe i Aabenraa, hvoraf 1. trop husede orkestret og 2. trop en ulveflok $^{24}$. Derudover hørte troppene i Løgumkloster, Graasten og Rødekro til kolonnen. I de første førermøder besluttede man at deltage $i$ salget af landeværnsmærker samt at anskaffe en fodbold til ca. 15 kroner, idet man "havde bemærket, at flere af de store spejdere viste dette spil interesse." Det var jo før de tætklippede fodboldbaners tid. En græsmark og nogle stokke som målstænger var alt nok. De to tropsførere ønskede flere marchøvelser med spejderne, så de blev bedre til at formere kolonne, og der afholdtes samariterkursus under ledelse af læge frk. Johansen.

Men langt større opgaver meldte sig. Den første var Kongeå Divisionens turnering i Bededagsferien 1927 i Aabenraa. Ledelse og tilrettelæggelse lå i divisionschef Madvigs hånd, men mange praktiske gøremål påhvilede naturligt nok lokale folk. Der deltog omkring 400 spejdere fra Vejle i nord til grænsen i syd. Turneringen afvikledes i Hjelm Skov og på ringriderpladsen ${ }^{25}$. Der konkurreredes i tovtrækning, trekamp, patruljevandring, spejderløb, lejrbålsunderholdning og lejrsport. Alle spejdere var privat indkvarterede. Præsidiet bestod af H.P. Hanssen, amtmand Kresten Refslund Thomsen, borgmester Holger Fink, skoleinspektør Jens Thau, rektor Mogensen, farvermester Thorkild Jacobsen, museumsbestyrer P. Møller samt Rosent og Simonsen. Ved det første lejrbål talte H.P. Hanssen. Selv om turneringen fik et godt forløb, blev den ingen succes for Aabenraa-spejderne. Troppene blev ikke placeret blandt de bedste. Haderslev løb med rævehale ${ }^{26}$ og sølvtøj. Det var en stor skuffelse for Simonsen, der havde regnet med, at 2. trop havde kunnet placere sig. 
en kongemodtagelse i Haderslev samme dag, for hvilket Simonsen modtog meget kritiske kommentarer fra Madvig. Forholdet mellem de to spejderchefer var ikke det bedste.

Den 15. juni markerede kolonnen syvårsdagen for genforeningen med en march fra statsskolen til Folkehjem. Heri deltog foruden spejdere også elever fra statsskolen samt omkring et hundrede elever fra Borgerskolen ${ }^{27}$, de sidste under ledelse af skoleinspektør Jens Thau. I den anledning anskaffede kolonnen med støtte fra Sprogforeningen seks meget store Dannebrogsfaner, der fordeltes over optoget. »Aldrig før har kolonnen markeret sig så flot«, skriver Simonsen. »Det var strålende solskin og en herlig dag«, men da kolonnen om aftenen mødtes for at foretage endnu en march, var det blevet rigeligt. "Det er en tur, der ikke bør gentages. Stemningen var mat«, noterer Simonsen. Man kan feste for meget.

Samme sommer drog 2. trop i sommerlejr ved Blåvand, og ti store spejdere ${ }^{28}$, fortrinsvis fra 1. trop, deltog i det svenske spejderkorps' jubilæumslejr ved Saltsjöbad nær Stockholm. De sønderjyske spejdere fik besøg af verdensspejderchefen Robert Baden-Powell og efterfølgende af den svenske spejderchef, major Ebbe Lieberath, ledsaget af den finske og norske spejderchef. Ved den lejlighed overrakte sønderjyderne de svenske spejdere et af de Dannebrogsflag, der havde vajet på Dybbøl ved festen i 1920 .

Fra lejren i Blåvand hedder det $\mathrm{i}$ et lejrbrev til de lokale aviser bl.a.: "Vort Dannebrog har vi anbragt på en meget høj flagstang, og den er sat op på den højeste klit i miles omkreds, hvorfra vort dejlige flag kan ses viden om«. Ingen skulle være i tvivl om, at det var danske spejdere fra Sønderjylland, der her lå i lejr.

Vel hjemme efter sommerens lejre forberedte kolonnen sig på at deltage $\mathrm{i}$ Matahelakrigen, en storstilet terrænøvelse med deltagere fra Fyns Division og Kongeå Divisionen. Den store øvelse, der var tilrettelagt efter rent militært forbillede, omfattede en forudgående periode med mobilisering, alarmeringsøvelser og gensidig spionage. Kongeådivisionens »styrker« blev ledet af løjtnant Thyge Johansen, Sønderborg. Sidst i august mødte de to divisioner til den afgørende dyst $\mathrm{i}$ området vest og syd for Fredericia. Her sejrede Fynboerne, omend knebent. De deltagende Aabenraa-spejdere blev transporteret til øvelsesområdet $\mathrm{i}$ fem lastbiler, og øvelsen varede til næste dags eftermiddag. Simonsen noterede om øvelsen : "Det var en meningsløs anstrengende øvelse, for militært anlagt. Spejderne bør ikke oftere deltage i den slags øvelser«.

I september arrangerede kolonnen i stedet for kolonneturnering en festdag med march gennem byen, parade ved Folkehjem, gudstjeneste i Sct. Jørgens Kirke og fest om aftenen på Folkehjem, hvor kaptajn C.C. Fischer ${ }^{29}$ talte. I oktober var der kolonneudrykning til Rødekro og Rise, og samtidig besluttede 


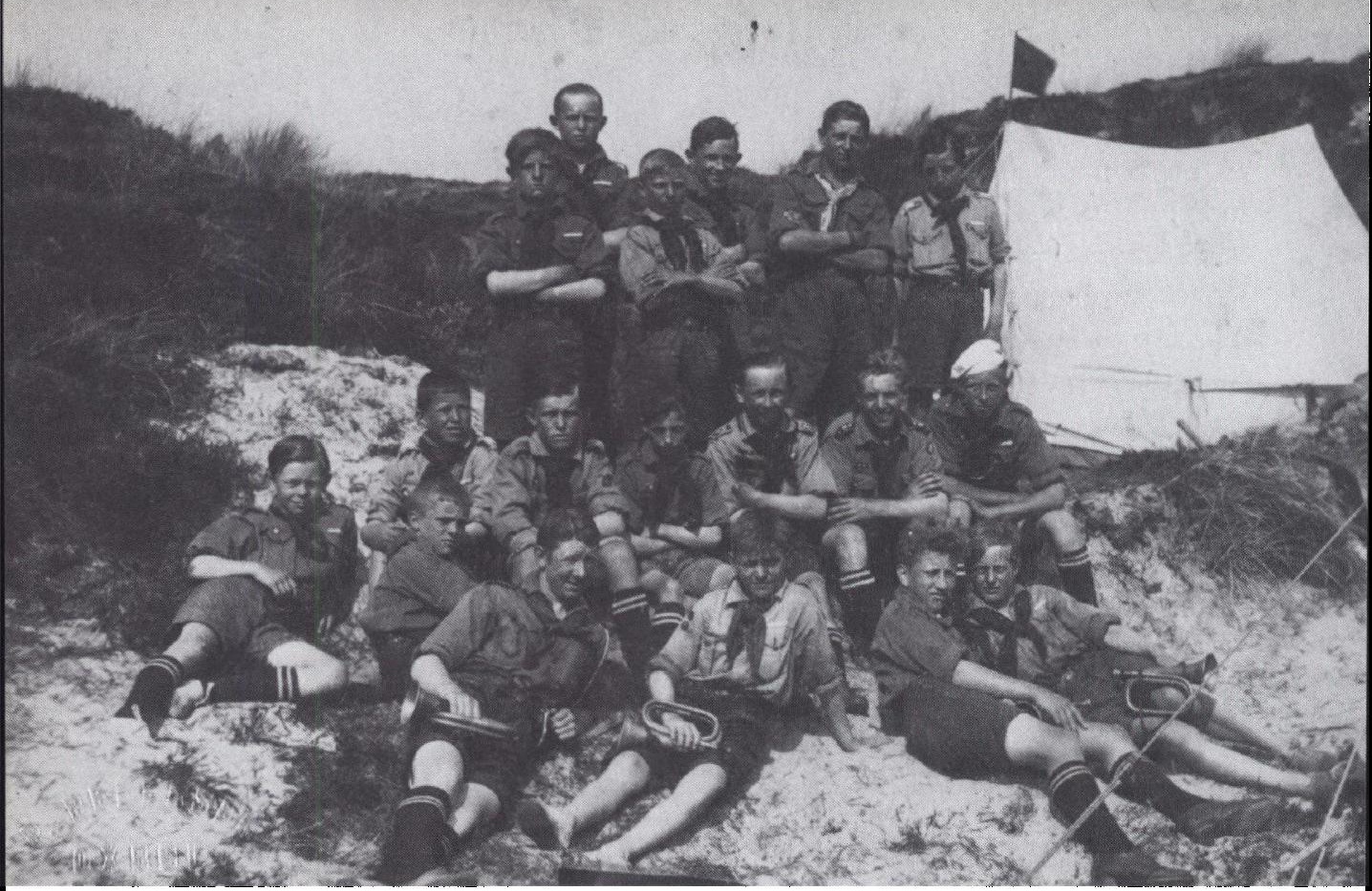

I 1920erne var Blăvand det foretrukne mäl for sommerens lejre. Dér kunne en Aabenraa-borger, grosserer Springhorg, stille lejrplads til radighed. Billedet er fra 1922/23, hvor spejderne har släet lejr midt $i$ klitterne.

Stående som nr. et f.v.: Hans Juhler. I midterrakken siddende f.v.: Poul Christoffersen, Hendrik Juhler, Valdemar Falck, Peter Tiedemann, Hans Falck og Nis Schmidt.

Liggende foran f.v.: Walter Jensen, Nr. to fra hojre: Marco Petersen og yderst t.h.: Knud Falck.

kolonnen at udgive et kolonneblad "Spejderposten«, der ville koste $45 \mathrm{kr}$. for 200 eksemplarer og skulle finansieres ved annoncer. Der udkom i alt fire numre af dette blad, det første i 1927 og de følgende i 1930, 1931 og 1932.

I december afholdt kolonnen en velgørenhedskoncert på Folkehjem til fordel for Kogeforeningen og Asylet ${ }^{30}$. Heri medvirkede foruden spejderorkestret et ensemble, hvor læge Frits Clausen, Bovrup og farvermester Jacob Jacobsen spillede. Jacob Jacobsen blev under besættelsen den første leder af modstandsbevægelsens syd- og sønderjyske region, medens Frits Clausen i trediverne blev "fører" for Danmarks Nationalsocialistiske Arbejderparti. I tyverne deltog han aktivt i det danske folkelige arbejde på egnen.

I efteråret 1927 knyttedes bankassistent Christian Wive til kolonnen som sekretær. Wive, der stammede fra Harreslev vest for Flensborg, havde været spejderfører i Flensborg, men var nu bosat i Aabenraa. I 1928 blev han udnævnt til kolonneassistent. At Wive knyttedes til arbejdet skulle vise sig at blive af stor værdi.

Også i 1928 skulle kolonnens aktivitet blive omfattende. Fra påskelørdag 
til anden påskedag arrangeres således en tur til København. Netop denne rejse fortjener at blive næunt, fordi den afslørede et dårligt forhold mellem spejderledelsen i København og den lokale kolonnechef i Aabenraa. Både Grænseforeningen og Det Danske Spejderkorps var blevet bedt om at hjælpe, men begge så sig ude af stand til at opfylde ønskerne, bl.a. fordi det drejede sig om påskedagene. Først da man ad omveje fik kontakt med dagbladet Politiken lykkedes det. Bladet omtalte de sønderjyske spejdere, der gerne ville til København, men ikke kunne finde overnatningsmulighed. Videre henvendte Politiken sig til viceskoleinspektør H.A. Svane, der var formand for korpsrådet. Han sørgede for overnatning på Bryggervængets Skole ved Svanemøllevej, hvor skoleinspektør Østergaard tog sig meget venligt af spejderne. Denne udgang af sagen foranledigede kolonnen til at sende Politiken en telegrafisk tak: "Fra Aabenraa spejdere samlet på Folkehjem«.

Da de 50 spejdere, hvoraf 18 udgjorde orkestret, ankom til Københavns hovedbanegård, blev de modtaget af Svane, der blev takket med et Tjikkerlikker og musik. Derefter drog "spejderne gennem København under vajende faner og brusende musik. På det sidste stykke vej til skolen fulgte hele Østerbro's ungdom med». Dagene gik med besøg på museer og i Zoologisk Have. Anden påskedag musicerede orkestret foran Rådhuset, og efterfølgende var alle spejdere af direktør Anton Petersen, Restaurant Wivel, inviteret til en festfrokost på den mondæne restaurant på hjørnet af Bernstorffsgade og Vesterbrogade. Under opholdet fik spejderne stor hjælp af en sønderjyde, direktør Thomas S. Lorenzen, der formentlig er den, der har foranlediget invitationen fra Wivel.

Korpsets manglende hjælp til aabenraaerne kom ikke til at gå upåtalt hen. I Aabenraa tolkede man den manglende hjælp fra København som en kritik af det lokale spejderarbejde. I en efterfølgende brevveksling viste Simonsen sin skuffelse og tog sin kolonne i forsvar. Han henviste til den stærke konkurrence, man havde fra de tyske Pfadfindere, der fik gratis udstyr og pengehjælp sydfra. "Det er ikke alene af spejdermæssige grunde, men også af nationale grunde, at det simpelthen nationalt set er nødvendigt, at der er en spejderafdeling i Aabenraa«, slutter Simonsen. Besøget og den efterfølgende korrespondance markerer således også forskellige holdninger hos korpsledelsen og ledelsen i Aabenraa.

I dag må vi nok sige, at reaktionen i Aabenraa var lidt overilet. Korpsrådets formand havde jo dog vist sig meget hjælpsom. Simonsens skarpe udfald skal derfor nok også ses i forbindelse med problemerne omkring Gravenshovedlejren samme år (se nedenfor). 


\section{Hytterne}

I 1925 blev »æ Kleinbahn« fra Aabenraa til Logumkloster nedlagt og erstattet af rutebildrift. Derved blev materiel og bygninger ledigt. Kolonnen erhvervede den hidtidige ekspeditionsbygning ved Knappen Holdeplads. Den var opført i 1899 på lejet grund efter aftale med restauratør Kunkel, Knappen og købtes nu for $150,-$ kr. Huset var af beskeden størrelse, ca. $35 \mathrm{~m}^{2}$, men så solidt, at kolonnen, da den flyttede derfra, kunne sælge taget og tømmerkonstruktionen til anvendelse til bygning af et nyt hus. Da spejderne overtog den gamle ekspeditionsbygning, noterede Simonsen, at huset nu burde have et dansk navn og ikke det tyske Knapp, hvorefter det blev døbt Stentofthytten. Ligesom den nyopførte ulvehytte i Blaasholm var den beregnet til overnatning uden for teltsæsonen. Stentofthytten blev anmeldt til korpsets hyttefortegnelse og var således til disposition for alle spejdere.

Indvielsen af de to hytter fandt sted på samme dag, den 8. juli 1928, ved en stort anlagt spejderdag, hvor spejdere lørdag aften slog lejr ved Stentofthytten og næste morgen fik serveret morgenmad. Derefter march til Aabenraa med parade på Statsskolens plads, indkvartering til middag, og om eftermiddagen march tilbage til Stentofthytten og efterfølgende til ulvehytten. Flagene blev begge steder hejst af kaptajn C.C. Fischer. Ved Stentofthytten holdt amtslæge dr. med. Mads Michelsen festtalen, og ved ulvehytten talte den tidligere kolonnechef Viggo Rosent. På hjemvejen til Aabenraa var der terrænleg i Jørgensgård Skov.

Med etableringen af disse to hytter var et længe næret ønske blevet opfyldt, og de udfyldte da også i nogle år deres funktion. Stentofthytten viste sig dog hurtigt at være for beskeden i størrelse, ligesom vedligeholdelsesomkostningerne blev store. I 1931 opførtes derfor en helt ny stråtækt hytte nær skov og strand ved Aabæk, hvor Statsskovvæsenet stillede et areal til rådighed. Denne hytte blev optaget $i$ Herbergringens hyttefortegnelse og var således til rådighed for walle spejdere og andre vandrere«, men det forudsatte, at man klarede sig selv, hentede nøgler hos en gårdejer i Aabæk, fyrede op i komfur og pejs og selv lavede mad og var tilfreds med at sove på hessianmadrasser på loftet under stråtaget.

Spejdernes Aabækhytte blev således egnens første vandrehjem og som andre spejderhytter landet over forgænger for nutidens mere luksuriøse vandrehjem. At hytten blev vandrerhytte, blev også dens skæbne. Sct. Hansaften 1936 endte hytten som egnens største Sct. Hansbål. Den nedbrændte på grund af nogle vandreres uforsigtighed med åben ild. Men allerede året efter besluttede kolonnen at bygge en ny hytte, der ifølge nye fredningsbestemmelser blev placeret noget længere fra kysten, men stadig på et naturskønt sted, hvor den også i 
dag, men uden stråtag, udfylder sit formål som spejderhytte. Rektor Mogensen viste Åbækhytterne stor personlig interesse, idet han, som rektor Hartvig Møller, var meget optaget også af vandrerbevægelsen.

\section{Affæren i korpslejren ved Gravenshoved 1928}

Det Danske Spejderkorps havde fastlagt, at der i 1928 skulle afholdes korpslejr. Af geografiske muligheder pegedes på Sønderjylland (Nordslesvig), Bornholm og Fyn. Da korpset omkring årsskiftet 1927/28 endnu ikke havde udpeget en lejrplads, opstod der, også i pressen, rygter om, at korpset, af grænsepolitiske grunde, ikke ønskede lejren placeret i Sønderjylland. Disse rygter afvistes dog af formanden for korpsrådet, viceskoledirektør H.A. Svane, der udtalte, at det alene drejede sig om at finde den rigtige lejrplads med de nødvendige muligheder for øvelser m.v. At der dog kunne ligge nationale undertoner bag overvejelserne peger en udtalelse af redaktør Andreas Grau på, idet han i Dybbølposten skrev: "Fordi vi er et grænseland, skal vi ikke tilsidesættes. Tyskerne søger systematisk at drage deres ungdom herop for at se landet. De holder stævner her og har bygget herberger for deres spejdere ${ }^{31}$ med plads til flere hundrede mennesker hver nat. Hvorfor må dansk ungdom så ikke også se landet? « Medlem af korpsledelsen, landsretssagfører Tage Carstensen stemte ikke den begyndende debat mildere, da han til Berlingske Tidende udtalte, at man måtte undersøge mulighederne både i Sønderjylland, på Bornholm og Fyn og fortsatte: "Med hensyn til Sønderjylland er der den fare, at der kan opstå et politisk moment, og det vil vi nødigt udsættes for, idet spejderbevægelsens formål er internationalt kammeratskab«.

Denne udtalelse udløste skarpe kommentarer fra bl.a. Flensborg Avis, hvor formentlig Ernst Christiansen spurgte, om det var blevet udæskende at afholde dansk spejderlejr på dansk grund og fortsatte: »Ethvert ærligt folk, også det tyske, vil betakke sig for internationalt at være kammerat med et andet, som nationalt er en karklud «.

Dannevirke skrev 9. januar 1928: "Er det den rådende opfattelse i Det Danske Spejderkorps, at spejdere ikke, af politiske grunde, kan opslå lejr i en hvilken som helst egn af Danmark, da er der mange forældre, som snart skal blive færdige med den institution. Så vi vil tro, Kongeaa Divisionen ganske vil forsvinde af mangel på medlemmer.«

Også H.P. Hanssen blev spurgt og udtalte til flere blade: "Jeg betragter det som sørgeligt, at en dansk mand kan nære betænkeligheder ved at opslå en dansk spejderlejr inden for landets grænser........ Ingen finder på at hindre tyskere i at holde deres store sportsstævner på Knivsbjerg. Hvor er vi i grunden 
henne, hvis den betragtning slår igennem her i landet, at det er i sin fuldkomne orden, at vi slår porte og døre vidt op for den tyske ungdom, men helst skal sende vores egen ungdom til Bornholm for at undgå en formentlig politisk fare, ved at man lægger den danske spejderlejr i Sønderjylland? Det er ikke for meget sagt, at denne udtalelse har vakt dybtgående bitterhed og harme $\mathrm{i}$ alle danske kredse."

Men Berlingske Tidende rykkede Tage Carstensen til undsætning og skrev, at udtalelsen ikke med rette kunne tilskrives Tage Carstensen, idet han kun havde refereret anskuelser, der skyldtes en mindre kreds inden for spejderledelsen, "vel nærmest repræsenteret ved navne som den ikke ukendte rektor Hartvig Møller«.

Korpset kunne naturligvis ikke undlade et svar. Det kom $\mathrm{i}$ form af en diplomatisk redegørelse fra Svane under overskriften: "Den kedelige diskussion om sommerens spejderlejr«. Heri peger han bl.a. på de problemer, der er at løse ved en sådan lejrplads, såsom drikkevandsforsyning, hospitalsadgang, bademuligheder m.v. og fortsætter: "Vel er der en enkelt eller et par stykker, der havde betænkeligheder ved at tage til Sønderjylland af hensyn til at en og anden herhjemme kunne misforstå lejrens henlæggelse til Sønderjylland og lægge noget andet deri end korpset selv har villet, derimod har der ikke været tale om nogen ængstelse over for naboen mod syd. Det seneste kolporterede rygte om, at korpsledelsen skulle have henvendt sig til pastor Schmidt, Vod$\operatorname{der}^{32}$, savner endog ethvert grundlag, hvorimod det er mættet af en ondskabsfuld fantasi." Videre skriver Svane, at korpset ikke kan hæfte for, hvad enkelte medlemmer mener og slutter: "Vi har da alle også været af den opfattelse, at vi ville have lejren i Sønderjylland, og at korpset nu venter på forslag fra Sønderjylland. Det er vort håb, at et hjerteligt møde vil være muligt ........ når vi i den kommende sommer får vort onske opfyldt om at slå vore telte op i det genvundne land."

De ønskede forslag lod ikke vente længe på sig. Divisionschef Madvig havde arbejdet med opgaven i nogen tid og bl.a. henvendt sig til Simonsen herom. Kolonnen foreslog, efter en foretagen rekognoscering, at lejren placeredes ved Eliselund på sydsiden af Aabenraa Fjord; men på Madvigs bord lå også andre forslag, nemlig et mere fra Aabenraaegnen, et fra Kollund, to fra Als og endelig en placering ved Gravenshoved syd for Hejls. Valget faldt på pladsen ved Gravenshoved. Denne afgørelse blev i nogle sønderjyske kredse opfattet som en svaghed, fordi pladsen lå så langt fra den nye grænse som gørligt. Men ved lejrens åbning talte H.P. Hanssen og Svane. Ingen af dem kom dér ind på den forudgående meningsudveksling.

Afgørelsen blev modtaget meget negativt i Aabenraa og medvirkede sikkert til, at Aabenraas kolonne slet ikke deltog i lejren. Så sent som en uge for 
lejrens åbning måtte Simonsen meddele Madvig, at kolonnen end ikke var $\mathrm{i}$ stand til at sende en patrulje. Årsagen var, anførte han, alene trykkende økonomi, men samtidig opnåede Simonsen hos Madvig tilladelse til, at kolonnen aflagde lejren et besøg.

Den 15. juli samledes kolonnens spejdere et stykke fra lejren, formerede marchkolonne og begav sig, med orkestret i spidsen, på vej mod lejrens hovedindgang. $150 \mathrm{~m}$ for denne blev kolonnen imidlertid standset af de to ledende medlemmer af lejr- og korpsledelsen, Ove Holm og Jens Hvass. Kolonnen blev anvist at marchere ad en sidevej til en skov, hvor den gjorde holdt, mens der på diskret afstand fandt en ordveksling sted mellem Ove Holm og

Chefen for det Danske Spejderkorps, civilingenior Ove Holm (1894-1969), aflagde i 1929, $i$ anledning af Flensborg-spejdernes 10-års-jubilaum, et besog i Flensborg. Ove Holm var patruljeforer for Danmarks forste spejderpatrulje. Siden fulgte mange andre og storre opgaver, hvoraf den betydeligste blev ledelsen af Det Danske Spejderkorps fra 1924 til 1960. en periode, hvor arbejdet udviklede sig starkt bäde kvantitativt og kvalitativt. I dette arbejde var Ove Holm det samlende midtpunkt, den naturlige chef, beskeden i fremtraden, men klar og sikker, når det gjaldt om at fastholde og udbygge arbejdet $i$ overensstemmelse med spejderbevagelsens grundlaggende enkle principper om et fornojeligt og karakterudviklende friluftsliv pả spejderidealernes grund. $P a ́$ denne baggrund bor hans holdning $t i l$ arbejdet $i$ Aabenraa bedommes.

På billedet ses Ove Holm ombord på en fjordbùd sammen med spejdere fra Aahenraa's orkester. T.v. Knud Skifter Andersen og t.h. Hanni Christensen.

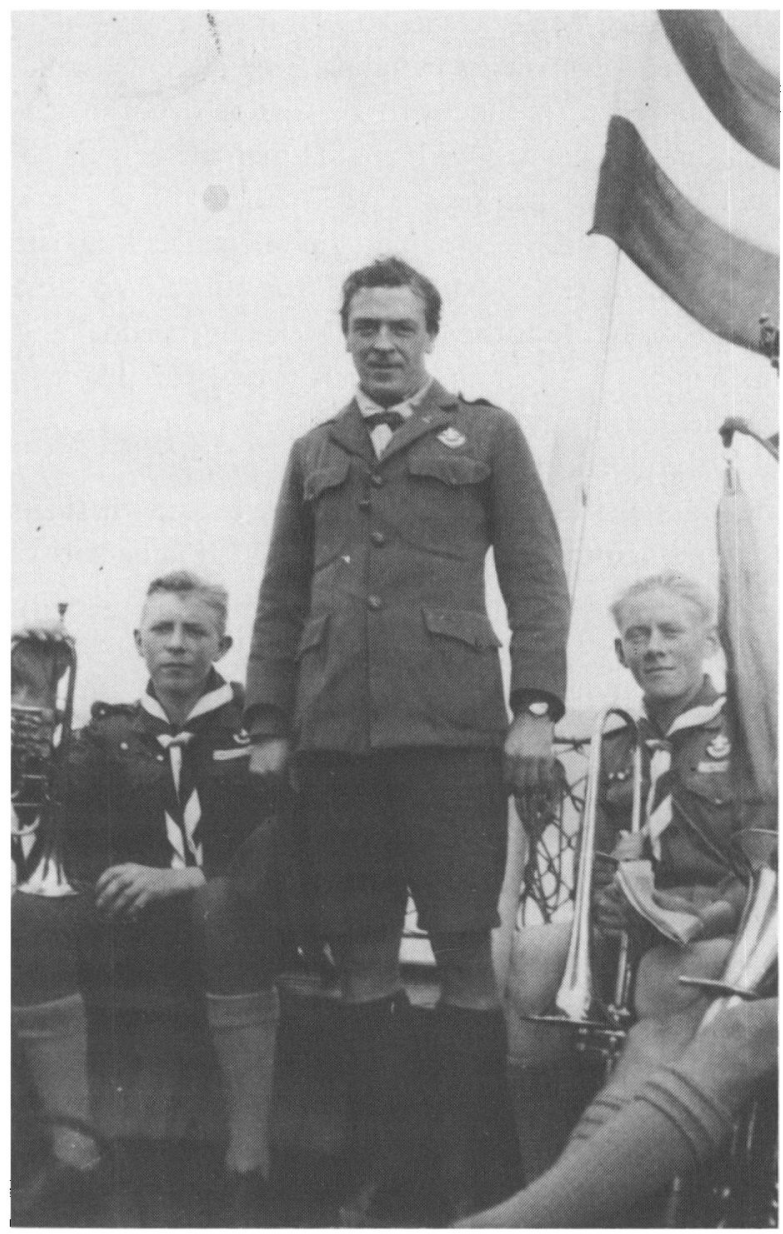


Simonsen. Det fremgik heraf ${ }^{33}$, at Ove Holm var meget forundret, ja ærgerlig over kolonnens besøg. Han stod uforstånde overfor, at den ikke deltog $i$ lejren som andre afdelinger og opfattede fraværet som en demonstration mod, at korpset ikke havde valgt lejrpladsen ved Eliselund.Dette imødegik Simonsen, idet har medgav, at lejrpladsen ved Gravenshoved var bedre egnet end den ved Eliselund. Det skyldtes alene økonomien, at Aabenraa ikke deltog. Det kunne Ove Holm ikke acceptere, man havde dog råd til at køre hertil i store biler og afholde udgifter til et orkester, der ikke havde noget med spejderarbejde at gøre. Simonsen forstod ikke den modtagelse, kolonnen fik, idet han havde et skriftligt tilsagn fra Madvig om, at kolonnen var hjertelig velkommen. Dette tilsagn var Ove Holm ubekendt, og det kom derpå til en meningsudviksling om spejderarbejdet i Aabenraa. Ove Holm ville ikke kalde det spejderarbejde, mente at det var »en ungdomsforening med musik " og kritiserede den stærkt nationale linie, arbejdet havde. Spejderbevægelsen var international. Da Simonsen henviste til det arbejde tyskerne udførte for deres Pfadfindere, mente Ove Holm, at man burde samarbejde med dem i stedet for at konkurrere med dem. Ove Holm var også stærkt kritisk over for rektor Mogensens stærke nationale holdning. Dette afviste Simonsen med, at »det var ham og ikke rektor, der lagde linien, o og at det var ham, der "måtte skaffe drengene fornøjelser«. Ove Holm meddelte, at korpset så alvorligt på forholdene i Aabenraa, at man overvejede ikke at godkende kolonnen som medlem af korpset.

Derefter forlod Ove Holm stedet, og Jens Hvass tog over. Det blev aftalt, at kolonnen kunne få adgang til lejren ad en sideindgang, der førte lige til lejrbålspladsen, hvor instrumenter m.v. kunne opbevares, mens spejderne beså lejren. Orkestret måtte ikke spille i lejren. Da kolonnen igen marcherede mod lejren, opstod der et lille intermezzo, idet orkestret påbegyndte en marchmelodi, som Simonsen dog fik standset under henvisning til, at der var middagshvil i lejren.

At det var en bitter og frustreret kolonnechef, der vendte hjem til Aabenraa i spidsen for sine spejdere, er fuldt forståeligt. Simonsen var draget af sted, efter at divisionschefen havde meddelt, at kolonnen var velkommen, og så var han på det nærmeste blevet afvist uden for lejrens port. Ove Holm blev dog hurtigt klar over, at der var sket en fejl. Da han og Jens Hvass mødte kolonnen uden for lejren, var de ikke bekendt med Madvigs brev, og at andre medlemmer af lejrledelsen havde godkendt besøget. Kommunikationsbrist og manglende kontakt til Madvig, der under lejren i øvrigt var sengeliggende nogle dage, var årsag til misforståelsen. Men korpsets reaktion skal også ses i lyset af, at korpslejren ikke havde fået den forventede tilslutning fra korpsets afdelinger. Der deltog således kun 1200 spejdere mod forventet omkring 4000. På den 


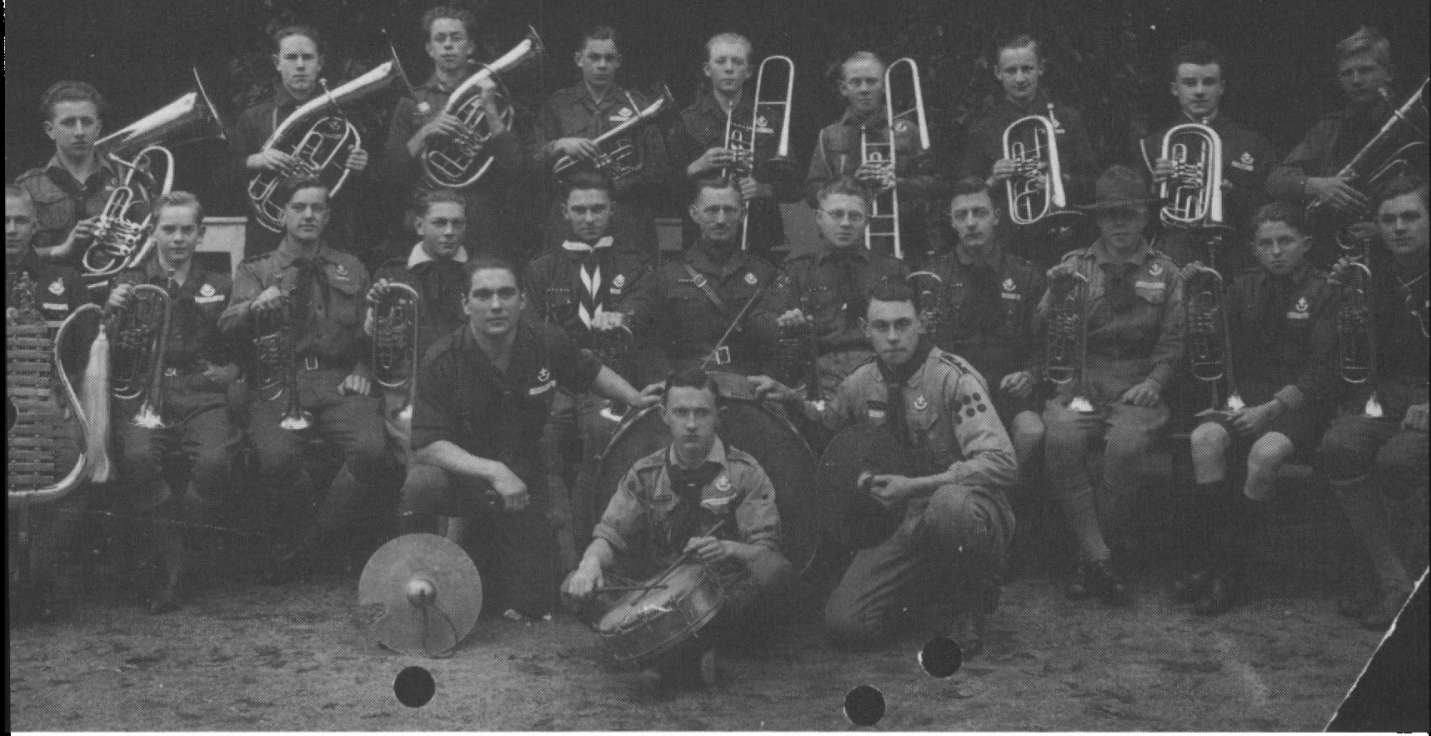

Spejderorkesteret 1927. Stående fra venstre: Magge Petersen, — Nielsen, Harald Uldall, Moritz Juhl, Knud Skifter Andersen, Hanni Christensen. Viggo Petersen, Jorgen M. Knudsen og Heine Bock.

Siddende fra venstre: Carl Poulsen, Carl Mortensen, Knud Falck, Fritz Logsti Hansen, Helmuth Hansen, P. A. Tegewaldt, Willy Tegewaldt, Peter N. Andresen, Harald Lorenzen, Jorgen Tegewaldt og Enfried Knudsen.

Foran: Willy Weingart, Hans Lassen og Hermann Jacobsen. P.A. Tegewaldt (1877-1956), orkesterets fittige og samvittighedsfulde dirigent $i$ de mange år fra 1921 til 1956, bortset fra en syvärsperiode, var oprindelig militarmusiker i Haderslev, men fik 1909 ansattelse ved postvasenet i Aabenraa. Ved genforeningen overgik han til ansattelse ved det danske Post- og Telegrafvasen med ansattelse ved Ingenierdistriktet $i$ Aabenraa.

baggrund var det særligt påfaldende, at Aabenraa Kolonne med omkring 200 spejdere helt var udeblevet på trods af, at netop den kolonne havde udfoldet stor agitation for lejrens placering i Sønderjylland, omend primært ved Eliselund. At det kunne være et økonomisk spørgsmål afviste korpset, idet deltagerne fra Aabenraa også skulle have betalt fuldt lejrkontingent ved deltagelse $\mathbf{i}$ en lejr ved Eliselund. Hertil kom, at Gravenshoved lå så nær Aabenraa, at man kunne cykle dertil i løbet af et par timer. Korpset forstod, naturligt nok, heller ikke, at kolonnen havde været $i$ stand til at arrangere en påsketur til København for 50 spejdere og at sende 10 spejdere på lejr ved Stockholm, men ikke én eneste til Gravenshoved. Korpset opfattede i høj grad, og næppe uden grund, fraværet som en demonstration mod, at lejren ikke blev placeret ved Aabenraa. Men hertil kom, at man generelt var utilfreds med arbejdet $\mathrm{i}$ Aabenraa, som man ikke opfattede som et egentligt spejderarbejde, men, som Ove Holm udtrykte det: »en ungdomsforening med orkester «. Noget lignende havde Jens Hvass givet udtryk for under sin korte divisionschefstid i Sønderjyl- 
land omkring 1922. Arbejdet i Aabenraa blev ikke anset som et spejderarbejde i overensstemmelse med korpsets linie. Korpsets ledelse havde ydermere ingen forståelse for det stærkt nationale præg, arbejdet i Aabenraa havde, og forstod ikke, at det skulle være umuligt at samarbejde med de tyske spejderbrødre $i$ byen.

Heroverfor stod de stærke nationale følelser, der prægede det genvundne land, hvor man var lykkelige og glade for genforeningen og alt dansk, men hvor man også levede under det pres, der udøvedes af tyske nord og syd for den nye grænse. I Aabenraa var spejderarbejdet og spejderorkestret populært. Således skriver adjunkt P.N. Mortensen ${ }^{34}$ i 1938 følgende:

"Hvilken Aabenraa'er lod være med at spidse øren, når drengene med "fader « Tegewaldt $\mathrm{i}$ spidsen drog gennem byen, ja, selv en hjemmetysker indrømmede, at de spillede godt. "Det var kun nogle forkerte melodier«. Jeg syntes netop, at det var fortræffeligt, særlig i den tid, at vore smukke nationale sange med fynd og klem lød over den ganske by, ja over hele Sønderjylland, thi man kan knap nævne et sted hernede, hvor spejderne med musik og Dannebrog i spidsen ikke har vist sig«.

Disse sætninger udtrykker meget godt stemningen hos de fleste danske i byen.

Da Ove Holm blev klar over misforståelsen, afsendte han straks, nemlig den 31. juli, et brev til Simonsen, hvori han afgiver korpsets "mest uforbeholdne undskyldning for det passerede«, og udtrykker håbet om, at "Simonsen på trods af affæren vil fortsætte sit arbejde til gavn for ungdommen i Aabenraa《. Denne udgang af sagen blev modtaget med stor tilfredshed i Aabenraa, hvor Simonsen efter et $\mathrm{i}$ august afholdt førermøde kunne svare Ove Holm således:

"Jeg fik bemyndigelse til, på alle føreres vegne at meddele Dem og korpset, at vi alle derefter med glæde anser det gode forhold mellem korps og kolonne som genoprettet, ligesom jeg på alle føreres vegne skal og vil takke Dem, fordi De har givet sagen en så forstående og hensynsfuld behandling og afslutning.«

Simonsen ønsker dog samtidig at få at vide, hvorledes korpset vil stille sig, dersom Aabenraa Kolonne melder sig ud af Kongeaa Divisionen.

Kolonnens vrede havde nemlig i mellemtiden vendt sig mod divisionschef Madvig, hvem man bebrejdede, at han ikke havde sikret sig, at kolonnen ville blive godt modtaget, og at han under de givne omstændigheder burde have hindret kolonnen $i$ at tage afsted. Madvig fralagde sig dog ethvert ansvar. Han 
havde tilsagn fra to af de fire lejrledelsesmedlemmer og havde lørdag aften fået at vide, at kolonnen ville blive modtaget af lejrledelsen inde i lejren. Først søndag morgen forstod han, at modtagelsen skulle ske uden for lejren, og da var kolonnen allerede på vej mod lejren. Der var således næppe heller grund til at bebrejde Madvig noget, og et godt forhold til divisionen blev da også hurtigt genoprettet.

Formentlig var det kolonnerådets formand, rektor Mogensen, der herefter fandt det nødvendigt at præcisere kolonnens holdninger. Det skete $i$ en af rektor udarbejdet udtalelse, der vandt énstemmig tilslutning i kolonneråd og førerkreds og derefter sendtes til korpset underskrevet af Simonsen.

Udtalelsen havde følgende udformning: "I betragtning af den uforbeholdne beklagelse af det skete såvel fra korpset som fra divisionen vedtog rådet at fortsætte arbejdet i Det Danske Spejderkorps og Kongeå Divisionen. Rådet ønsker over for korpset at fremhæve to afgørende synspunkter for dets arbejde, som det stadig vil fastholde som nødvendige betingelser for dets fortsatte arbejde.

1) Det nationale: Rådet ønsker, at arbejdet inden for Aabenraa Kolonne skal gøres som et led i det nationale arbejde for at indføre sønderjysk ungdom i dansk kultur, idet det anser Det Danske Spejderkorps', arbejde for et værdifuldt led i dansk ungdomskultur. Der ligger heri intet fjendtligt over for andre nationer, heller ikke den tyske, der forlanges ingen bestemt nationalpolitisk indstilling som betingelse for optagelse. Medlemmer af det tyske spejderkorps vil altid, ligesom andre nationers spejdere, blive behandlet som kammerater, ligesom kolonnen ønsker at være med til at fremme international forståelse hos ungdommen. Rådet gør sit arbejde for at tjene den danske ungdom, og det ønsker, at danske skal vokse op i kærlighed til dansk land, og det vil sammen med den på besindig og værdig måde deltage i vore nationale fester. Rådet har enstemmigt vedtaget, at dets arbejde udføres ud fra den forudsætning, at det støtter et dansk arbejde for dansk ungdom.

2) Det sociale: Rådet ønsker, at arbejdet skal gøres på en bred folkelig basis, således at man gør sit yderste for at undgå, at det begrænses til overklassens ungdom, og det anser bestræbelserne for at slette sociale skel for et værdifuldt led i spejderarbejdet. Rådet forventer, at korpset $i$ sin bedømmelse af kolonnens arbejde vil tage hensyn til dette forhold $i$ erkendelse af, at ydelserne $\mathrm{i} ø$ konomisk og sportslig henseende vil blive noget præget af, at spejderne ikke udgår fra en snæver kreds af ungdom fra et ensartet og forholdsvis højt stående socialt lag«. 
Det interessante i denne udtalelse er ikke understregningen af det nationale, for det lå lige for i Sønderjylland i 1928. Det bemærkelsesværdige er, at man fremhævede det sociale. Selv om forældrekredsen var domineret af embedsstanden og af borgerlige erhverv, havde det helt fra 1919 været klart, at her var et dansk arbejde, hvor alle byens drenge burde kunne være med, og der kan da også tælles adskillige spejdere fra mere beskedne hjem, selv om arbejdet aldrig fik den helt brede tilslutning fra arbejderklassens drenge. I de fleste købstæder af Aabenraa's størrelse var der almindeligvis kun én trop, her var der to til tre troppe. Alene det betød større bredde i arbejdet, og der er da heller næppe tvivl om, at en undersøgelse af dette forhold ville vise, at spejderarbejdet her havde større social bredde end mange andre steder. Det skyldes næppe, at man i Aabenraa var særligt socialt indstillet, snarere, at man ønskede at inddrage flest mulige drenge $\mathrm{i}$ et dansk arbejde. Det var mere nationalpolitik end socialpolitik.

I Det Danske Spejderkorps' formålsparagraf fandtes et afsnit om "det nationale«. Den talte om »at fremkalde og styrke en bevidst fædrelandsfølelse hos ungdommen, således at den - $\mathrm{i}$ forhold til alder og modenhed - ser på hele sin optræden, sin udvikling og sit arbejde $i$ belysning af fædrelandets gavn og ære.« Den holdning kunne kolonnen fuldt ud tiltræde, ligesom korpset meddelte, at det ingen bemærkninger havde til kolonnens udtalelse. Der var intet modsætningsforhold i det sprogligt udtrykte.

\section{Dansk-tysk balancegang}

Lejren i Gravenshoved var ikke det eneste problem, kolonnen stødte på i 1927/ 29. Der kom også nogle af endnu mere udtalt nationalpolitisk karakter.

Da orkesterdirigent P.A. Tegewaldt fyldte 50 år i marts 1927, forærede spejderne ham en flagstang og et Dannebrogsflag til hans villa på Karpedam. Det gav anledning til disse bemærkninger i Apenrader Tageblatt (9. marts 1927):

"Det er en tvivlsom gave, spejderne har givet lederen af deres orkester, hr. postassistent Tegewaldt i form af en flagstang, som de har stillet op $\mathrm{i}$ hans have.

Tegewaldt var tidligere ikke alene tysk, men også tysksindet embedsmand og fhv. tysk militærperson, så gaven må være blevet modtaget med blandede følelser, og man må spørge, hvad den flagstang skal anvendes til. I vide kredse vil man i hvert fald betragte en sådan gave som en taktløshed fra spejdernes side." (her oversat fra tysk). 
Sådan så Tegewaldt nu ikke på det. Foruden at takke skrev han den 26. marts:

"Herved undlader jeg ikke at bemærke, at fordi der er andre personer, der mener, jeg er i tvivl om, hvad jeg skal bruge fødselsdagsgaven til, det er jeg absolut ikke, tværtimod, kære kammerater, skal flagstangen ved enhver given lejlighed benyttes til at hejse mit smukke flag«.

Men i sommeren 1929 meldte Tegewaldt fra. Han ønskede at trække sig tilbage, fordi han ikke fandt, at drengene opmarksomt nok fulgte hans undervisning. Men Simonsen var af den opfattelse, at hans tilbagetræden skyldtes vanskeligheder med og kritik fra Tegewaldts tysksindede musikerkolleger, fordi han foretrak danske spejdere fremfor tysk ungdom.

Det bør erindres, at Tegewaldt udførte sit arbejde for spejderorkestret uden nogen form for honorar. Dirigenthvervet var frivilligt og brødløst. I denne situation overvejede Simonsen at opløse orkestret, men det lykkedes ret hurtigt at finde en afløser for Tegewaldt, idet tilskærer H.A. Raahauge ${ }^{35}$ overtog arbejdet, hvis ledelse Tegewaldt igen påtog sig syv år senere. Flagstangen forblev på sin plads.

Efter den tidligere Flensborg-spejderfører, Wives tilknytning til arbejdet $\mathbf{i}$ Aabenraa forstærkedes bestræbelserne for at øge samarbejdet med Dansk Spejderkorps Flensborg. Et af de første initiativer var en plan om at lade kolonnen deltage $\mathrm{i}$ det danske årsmøde $\mathrm{i}$ juni 1928. Planen blev drøftet $\mathrm{i}$ en brevveksling mellem Wive og Viggo Lausten ${ }^{36}$ om pasproblemerne. Wive gik ud fra, at Aabenraa-spejderne kunne passere grænsen på fællespas, men dette frarådede Lausten under henvisning til en samtale med den danske konsul i Flensborg, der anbefalede, at man lod spejderne deltage ved personlige pas. Det skinner igennem Laustens breve, at denne holdning var dikteret af ønsket om ikke at skulle udstede fællespas til de mange tyske unge, der i disse år ønskede at besøge Nordslesvig. Slutresultatet blev, at kolonnen omend med beklagelse aflyste deltagelse i årsmødet, idet kun et fåtal af drengene havde eget pas.

I november 1928 afholdt Dansk Blindesamfunds sønderjyske afdelinger en fælles basar til fordel for blindesagen på Folkehjem i Aabenraa. Dette humanitære arbejde var altid søgt friholdt for nationale problemer, men i forbindelse med basaren opstod den tanke at lade byens uniformerede ungdomskorps marchere gennem byen som agitation for basaren. Kolonnen og pigespejderne godkendte, at de tyske Pfadfindere deltog heri, hvilket medførte protester fra forældre, der bebrejdede kolonnens ledelse denne disposition. På et kolonnerådsmøde i februar 1929 blev spørgsmålet efterfølgende drøftet. Simonsen 
mente, at man burde bøje sig for kritikken, medens Mogensen holdt for, at sådanne fælles arrangementer også fremtidigt burde kunne gennemføres. Mødet sluttede noget dramatisk med, at Mogensen stillede sit mandat til rådighed og anbefalede, at man fandt en formand, der fulgte Simonsens synspunkt. Problemet drøftedes på endnu et møde, uden at der blev truffet nogen egentlig beslutning, og Mogensen blev på sin post. At tyskerne heller ikke har haft det nemt ses af, at man gerne ville deltage, men ikke ønskede at marchere med helt ind i Folkehjems have, hvorfor de tyske Pfadfindere ud for Folkehjem drejede af mod Karpedam, bort fra Folkehjem.

Det nationalpolitiske var hverdag i Nordslesvig i disse år. Da der først på året 1929 fremkom rygter om, at man i Rødekro arbejdede på at oprette en Pfadfinder-trop, tog Simonsen straks initiativ til at genoplive et dansk spejderarbejde der. Kolonnen afholdt en spejderaften på Jernbanehotellet, hvor der meldte sig et antal drenge, og en spejdertrop blev dannet.

Det var en mangeårig tradition, at spejderne i Aabenraa på Valdemarsdagen, der også var Genforeningsdag, varetog salget af Danmarkssamfundets små Dannebrogsflag. I 1929 medførte dette en protest fra det tyske dagblad, Apenrader Tageblatt, der i skarpe vendinger beklagede sig over, at "vi tyske i vore egne boliger skal presses til at købe Dannebrog af ivrige spejdere«. I 1931 fik Simonsen dog optaget en mindre artikel i Apenrader Tageblatt om Det Danske Spejderkorps og dets arbejde. Den bragtes på tysk.

\section{Spejderarbejde i 1930 'erne}

Begivenhederne i og omkring Gravenshovedlejren skulle vise sig at blive indledningen til en bedre forståelse mellem korpset, divisionen og kolonnen. Rektor Mogensen skrev således i en historisk oversigt i 1945 ${ }^{37}$ : "Men spejderne var klar over, at der spejderteknisk var noget at indvende, og der var enighed om, at nu skulle det bringes i orden«. Det blev Wive, der med titlerne kolonneinstruktør og »Medicinmand «, påtog sig opgaven og den energi, hvormed han gav sig i kast med opgaven, viste hurtigt gode resultater. Men også korps og division satte nu kræfter ind på at styrke den spejdermæssige side af arbejdet i Aabenraa og bringe det på rette spor. Til Aabenraa-spejdernes store overraskelse tog divisionschef Madvig et initiativ, han lod afholde nogle forældre- og instruktionsmøder i Aabenraa. Men mere vigtigt end dette var dog, at korpsets førertræning, ved den myndige leder Jens Hvass, helt ekstraordinært indbød nogle førere fra kolonnen til at deltage i korpsets Gilwell-kursus i påsken 1929. Deltagelse $\mathrm{i}$ dette kursus forudsatte ellers, at deltagerne $\mathrm{i}$ 
den forudgående vintersæson havde gennemført og bestået et ret omfattende brevkursus. Men det var korpset i dette tilfælde villig til at se bort fra.

I sin begejstring over denne håndsrækning anmeldte Simonsen ikke færre end 17 førere, deraf 9 fra Aabenraa by. I betragtning af, at der normalt deltog en 20 - 30 førere fra hele landet $i$ et sådant kursus, der var en teoretisk/ praktisk træning gennemført under lejrforhold og forudsatte et solidt kendskab til og erfaring fra spejderarbejdet, beroede dette høje antal på en misforståelse. Jens Hvass måtte da også melde fra. Slutresultatet blev, at fire deltog ${ }^{38}$. Derudover deltog Hans Skjøth ${ }^{39} \mathrm{i}$ et særligt ulveførerkursus. Begge kurser afholdtes i Nordsjælland. Ulvekursus på Saunte og spejdergilwell på Hartvig Møllers prægtige areal, Storedam ved Allerød. Efterfølgende kunne Ove Holm, Jens Hvass og Tage Carstensen i et fællesbrev meddele Simonsen, at "vi var overordentligt glade for at have Deres fire folk på Gilwellkursus«. Man anbefalede samtidig, at disse nu »deltager i det teoretiske kursus, således at de derved får det fulde udbytte af kursus."

Episoden i Gravenshovedlejren blev ikke alene indledningen til et mere positivt samarbejde med korps og division, men også indledningen til en styrkelse af det egentlige spejderarbejde i kolonnen. Det skete gennem en styrkelse af arbejdet $i$ troppe og patruljer, gennem patruljeførerkurser og andre kurser og i 1932 ved afholdelse af en kolonnelejr ved Hindsgavl. Denne udvikling skete, uden at kolonnen gav afkald på at deltage $\mathrm{i}$ det nationale arbejde, ligesom man fastholdt orkestervirksomheden, dog at orkestret ikke mere deltog $i$ arrangementer uden for spejderarbejdets rammer. Samarbejdet med Flensborgspejderne udvikledes fortsat, og der fandt gensidige besøg sted, foruden at spejdere fra Aabenraa nogle gange deltog i de danske årsmøder.

Også divisionen søgte generelt at styrke spejderarbejdet gennem førerkursus, f.eks. i 1932 i Aabækhytten med Jens Hvass som leder og ved at ændre divisionsturneringerne til patruljeturneringer, hvorved alle spejdere fik mulighed for aktivt at deltage $\mathrm{i}$ opgavernes løsning. Tilsvarende afholdtes årlige kolonneturneringer. Resultatet af denne mere bevidste træning udeblev da heller ikke. I 1931 blev 2. trop således divisionens bedste ved en divisionsturnering i Kolding, idet troppen blev den bedste eller næstbedste $i$ alle opgaver bortset fra madlavning, hvor sønderjyderne var noget knotne over at få udleveret mel til frikadellerne. Man var da vant til at bruge rasp til sønderjyske frikadeller!

En medvirkende årsag til denne forbedring af det praktiske spejderarbejde var også, at det lykkedes at finde tropsførere, der varetog deres job i en længere årrække. Helt indtil 1929 havde der været tale om ret så hyppige førerskift. Af betydning for udviklingen var det ligeledes, at Wive i 1932 overtog ledelsen af kolonnen efter i en årrække at have været Simonsens højre hånd. Den større 


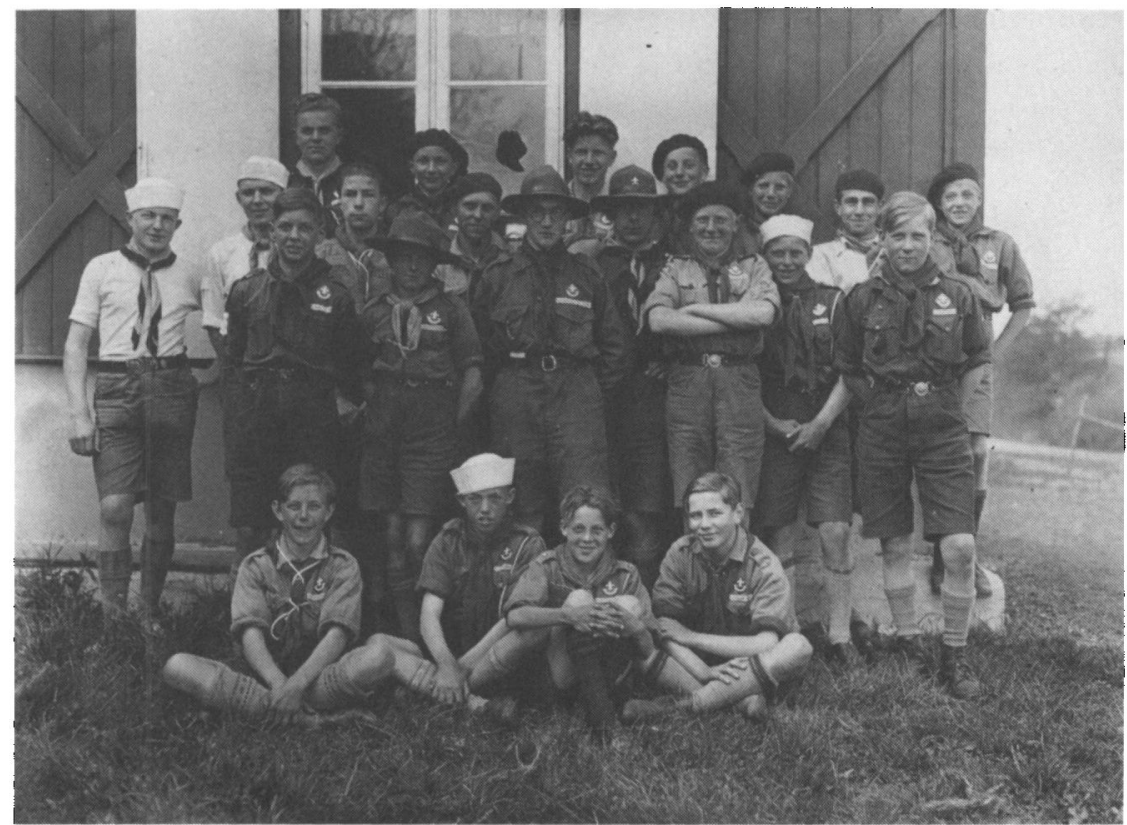

Til styrkelse af det praktiske spejderarbejde afholdtes i 1929 et patruljeforerkursus i Stentofthytten under ledelse af Christian Wive, der her ses i midten af kursusdeltagere og medvirkende.

Christian Wive (1901-73) knyttedes til kolonnen i 1927 og var dens chef fra 1932 til 1946. Han var fodt $i$ Harreslev ved Flensborg, hvor han havde varet med i spejderarbejdet siden 1919. Wive, der var bankuddannet i Union Bank, var ansat i Den Nordslesvigske Folkebank i Aabenraa, hvor han blev prokurist. Wive var en stilfardig, energisk og malbevidst chef for kolonnen, hvor han samlede en stabil kreds af forere. Han var den ledende bag oprettelsen af et Sct. Georgsgilde i byen sa tidligt som i 1934.

stabilitet i førerkredsen skyldtes næppe alene, at det daglige arbejde fik mere indhold, men også at den nationalpolitiske situation i grænselandet skærpedes i takt med Hitlers sejrsgang i Tyskland. Det styrkede de hjemmetyske kredse i hele deres arbejde og i deres krav om en grænseflytning. Dette øgede tyske pres medførte naturligt nok et forstærket dansk modspil og øgede interessen for det danske spejderarbejde, der var et af de steder, hvor man kunne fastholde unge $i$ et dansk miljø.

Da Simonsen afleverede kolonnen til Wive i 1932, bestod den af de tre troppe og ulveflokken i Aabenraa samt afdelinger i Graasten, Rødekro, Løgumkloster, Løjt-Genner og Hjordkær. Der var altså tale om en stor vækst i Simonsens fem år, et resultat af den vægt han og andre tillagde det agitatoriske og det nationale. "Talmæssigt kunne kolonnen ikke udvides«, noterer Wive da også, men mogså den sportslige og spejdermæssige udvikling havde gjort store fremskridt«. Han føjer dog til, »at ældre spejdere og førere længe havde 
næret store betænkeligheder ved den store udvidelse med nye troppe, navnlig landtroppene, idet man nærede den ikke uberettigede anskuelse, at disse troppe ikke lod sig opretholde«. Wive tænker her nok på vanskeligheden med at skaffe og fastholde førere over en længere periode. »Det må endvidere erindres, at medens Simonsen først og fremmest var interesseret $i$ at inddrage nye områder, måtte det som en selvfølgelighed gå ud over det egentlige spejderarbejde, og her var kolonnen langt tilbage. Bortset fra 2. trop kunne kolonnens troppe ikke siges at være spejdertroppe i sportslig forstand. Således blev det ikke nogen let arv, den nye ledelse fik. Hvad Simonsen med sine rige evner havde samlet, måtte nu, for så vidt der var grundlag, videreføres, og hvad der ikke kunne holde, måtte afvikles. Drengene havde været til fest og store glansfulde sammenkomster, nu må det gribes an på en anden bov«. Dette uddrag af et notat, udarbejdet af Wive, skildrer rimeligt godt arbejdets stilling.

I 1932 taltes 118 spejdere og ulve i Aabenraa by foruden de voksne førere. Medlemstallet var således øget med næsten $50 \% \mathrm{i}$ de fem år. Interessant er det, at af de 118 drenge var ikke færre end 31 spejdere over 16 år og deraf igen 12 over 18. Dette høje antal ældre drenge viser, at kolonnens troppe var i stand til at fastholde interessen også hos de store drenge. Det skyldtes sikkert både orkestrets mulighed for beskæftigelse og det nationale ståsted, som arbejdet indebar.

I de følgende år, hvor Wive var chef, lykkedes det yderligere at styrke og stabilisere selve spejderarbejdet, således at Aabenraa-spejderne fuldt ud kom på højde med spejdere andre steder. Det skete gennem et målbevidst og stabilt arbejde i kolonnens troppe, tilrettelagt således at man ikke svigtede den nationale opgave, der i trediverne blev endnu mere åbenbar. Orkestret fortsatte sin virksomhed, men tilrettelagt sådan, at også de musicerende spejdere kunne dyrke spejdersport. Da Wive holdt op i 1946, var der godt 200 spejdere og ulve i Aabenraa. Der var altså ikke alene tale om en stabilisering, men også om en stærk vækst. Antallet af »store« spejdere var fortsat stort.

\section{Sct. Georgsgildet}

Korpsets tilbud til store spejdere (17/18 år og derover) var roverarbejdet, der forudsatte lyst til fortsat frilufts- og lejrliv. Var man over 18 år, måtte man vælge mellem at være rover, fører eller at forlade korpset. Baggrunden var, at man ønskede at fastholde korpset som en børnebevægelse. Disse regler fandt Wive ikke egnede. Han mente ikke, at man kunne bygge et voksent spejderliv på lejr- og friluftsliv. "Der måtte findes noget mere voksent, som kunne interessere de unge $\ll$, noterede han. 
Den aktuelle situation beskrev Wive således:

»Det var netop i de år, fra 1930 til 1933, at Hitler kom til magten. Den stærke agitation derfra smittede af, navnlig på det tyske mindretal, der blev meget udfordrende og gang på gang optrådte i gaderne. Det var helt klart, at man måtte have visse modtræk for at kunne vise en stor og frisk ungdomsskare. I Aabenraa, som overalt i Sønderjylland (Nordslesvig), var tilslutningen til spejderbevægelsen meget stor Bevægelsen i Aabenraa var den gang mere nationalt præget end interesseret i spejdersporten. I byens gader så man ofte uniformerede korps af drenge og piger tilhørende det tyske mindretal. Det var derfor ganske naturligt, at de danske spejdere i bogstaveligste forstand søgte at holde fanen højt ... Det Danske Spejderkorps var en værdig repræsentant for et dansk ungdomsarbejde $\mathrm{i}$ årene efter genforeningen.«

Aabenraa ønskede ikke at bruge korpsets roverarbejde og søgte derfor efter "noget andet«. Derved opstod den tanke, at "vi måske burde have vort eget. Men det var klart, at vort eget for Aabenraa ville vi ikke lave. Det skulle være, om ikke landsomfattende, så i hvert fald dækkende Sønderjylland. Vi gjorde os mange tanker om, hvad det skulle være«, skrev Wive.

I de samme år arbejdede i København nogle tidligere spejderførere med planer om at samle »de gamle spejdere i een stor organisation, hvis formål skulle være i praksis at føre bevis for spejdertankens og spejderidealernes kraft ude i livet«. Et større møde herom fandt sted på Casino i april 1933. Det resulterede i bred tilslutning til at søge stiftet et Sct. Georgsgilde, en sammenslutning af tidligere spejdere.

I månederne derefter etableredes kontakt mellem Wive, Rosent og initiativtagerne i København, grosserer Erik Sjøquist, kaptajn Frode Heiberg Jørgensen og flagfabrikant Erik Dahl. Også rektor Mogensen blev inddraget i overvejelserne, og efter at kolonnerådet $i$ et møde den 26 . oktober 1933 havde givet grønt lys, indbød de tre til et forberedende møde på Folkehjem den 12. december 1933 med det formål wat søge dannet en civil sammenslutning af gamle spejdere $\lll$.

I et notat fremhæver Rosent, at det var »Wive, der i oktober/november førte forskellige orienterende forhandlinger til flere sider«, men det ses også, at Rosent deltog i hvert fald $i$ én forhandling med initiativtagerne $i$ København bl.a. om mødeform, ritualer m.v. At forhảbningerne kunne svinge en del ses af, at Rosent så sent som den 8. november 1933 til Wive skriver: »Jeg har 
ganske vist min stille tvivl om, at et Sct. Georgsgilde vil få en krank skæbne, men jeg vil meget gerne lægge navn til et forsøg, selv om det mislykkes«.

I mødet på Folkehjem deltog 24 førere og tidligere spejdere, der besluttede at stifte et Sct. Georgsgilde, der fik Rosent som gildemester, Jacob Michelsen ${ }^{40}$ som skatmester (kasserer) og Lorenz J. Hansen ${ }^{41}$ som kansler (sekretær). Derudover indvalgtes Wive og Hans Lassen ${ }^{42}$ i gildeledelsen. Alle i ledelsen var således mangeårige spejdere. I marts indvalgtes Rosent i den første landsgildeledelse som kansler.

Sct. Georgsgilderne i Danmark, som den landsdækkende bevægelse kom til at hedde, har således sit udspring i såvel København som i Aabenraa, i Aabenraa inspireret af det talstærke spejderarbejde, den nationalpolitiske situation og af Wives interesse for at finde frem til en form, under hvilken voksne kunne fortsætte en slags spejderbevægelse.

Sct. Georgsgilderne, der siden har fået en vis international udbredelse, fik vel aldrig den tilslutning, som bevægelsens fædre havde tænkt sig. Indtil i dag har tilslutningen i Danmark kun været på op mod 9.000 medlemmer. Dette lave tal skyldes nok, at omend man $i$ de unge år bindes sammen af fælles oplevelser og af spejderidealerne, så kan den sociale, kulturelle og uddannelsesmæssige baggrund være så forskellig, at det for voksne er svært at finde en fællesnævner. Hertil kommer vanskeligheden med at finde en form og et indhold, der interesserer både unge og ældre. Fælles minder fylder ikke nok.

Selv om Wive nu med tilfredshed kunne se, at en sammenslutning af gamle spejdere var dannet, opgav han dog ikke sine tanker om en direkte overbygning på det egentlige spejderarbejde, et voksent ungdomsarbejde, byggende på spejderidealerne og med et klart nationalt formål. I 1934 drøftede han denne tanke med Madvig, der ytrede interesse for at være med til at danne noget sådant for Sønderjylland. Tanken var, at korpsets afdelinger skulle have større selvstyre. Formentlig har det foresvævet Wive, at en sådan Sønderjylland omfattende ungdoms- (spejder) bevægelse kunne trives inden for korpsets udvidede og mere frie rammer. Madvig lovede at fremdrage tanken om større selvstyre i korpsets bestyrelse, hvor han var medlem. Dette skete da også i oktober 1934, og han fandt wen vis interesse for vore tanker, vi må komme med forslag, men det er sværere end vi tror «, skrev han 10 . oktober til Wive.

Herefter har Wive og Madvig formentlig henlagt sagen. Den ses ikke senere at være taget op, men Sct. Georgsgilderne var sat igang, og selv om de fik et meget voksent tilsnit, kunne man dengang være med fra det 18 . år. Også Det Unge Grænseværn var blevet dannet i 1933 og udviklede sig i løbet af meget kort tid til en altomfattende dansk ungdomsbevægelse »til værn om grænsen« og løste således den påtrængende nationalpolitiske opgave. 


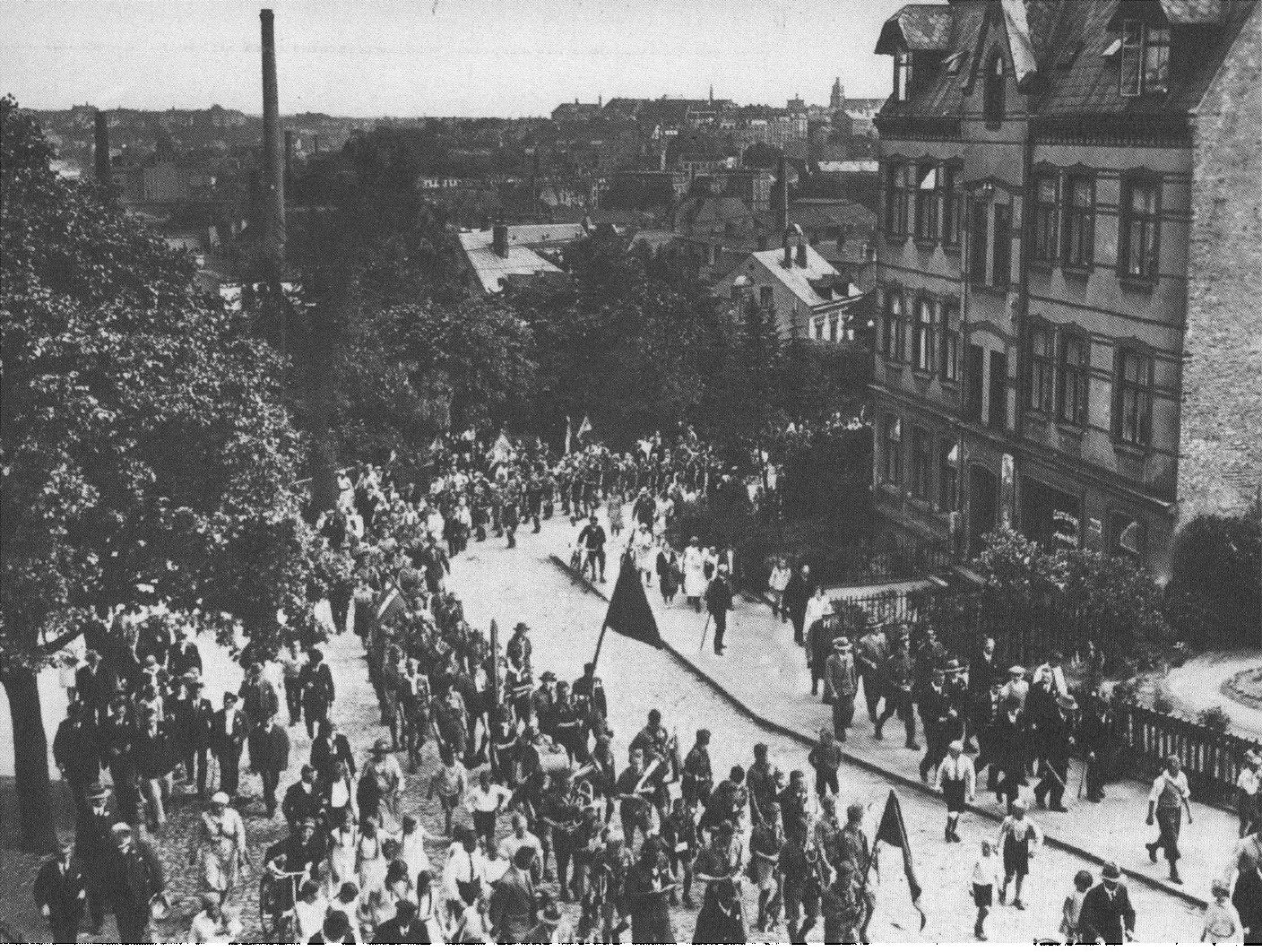

I 1923 indledtes et samarbejde mellem Flensborg-spejderne og Aabenraa Kolonne. Det forstarkedes fra 1927 gennem adskillige falles arrangementer, og Aabenraa-spejdere deltog flere gange $i$ danske årsmoder $i$ Flensborg. Billedet er fra 1932, hvor årsmødeoptoget ses på Bov Landevej. Foran i billedet Aabenraa's orkester. T.v. for den høje stander ses en tilhyllet Dannebrogsfane. Det var dengang ikke tilladt at frembare Dannebrog syd for gransen.

\section{Internationalt spejderarbejde $i$ et nationalt spændingsfelt}

I glæden over genforeningen med Danmark blev dansk spejderarbejde budt varmt velkommen i Sønderjylland, hvor det blev betragtet som et frisk dansk børne- og ungdomsarbejde, der kunne udfylde et tomrum i det $\mathrm{i}$ øvigt vidt forgrenede danske foreningsliv. Ledende danske sønderjyder viste arbejdet stor interesse, hvilket også mange nytilflyttede rigsdanske gjorde. Af stor betydning var det, at også en del ledende skolefolk interesserede sig aktivt eller mere passivt for arbejdet. At spejderarbejdet i Sønderjylland fra $1920 \mathrm{og}$ fremefter mere blev betragtet som et dansk nationalt arbejde end et udviklende og karaktertrænende frilufts- og lejrliv er forståeligt, for i 20'erne og 30'erne var udviklingen mellem dansk og tysk et problem, der dagligt optog alle. Spejderarbejdets nationale betydning fik en særlig understregning i de byer, hvor der oprettedes hornorkestre (Aabenraa, Flensborg og senere Tønder). I Aabenraa indgik orkestret ofte sammen med alle spejdere som et aktivt og 
skattet led i byens liv. Ofte mødtes spejderne med orkester alene for at afholde en parade og foretage en march gennem byens gader for at vise, at der var en dansk ungdom, og at den var talstærk. Man sang:

"Her kommer de raske sønderjyske drenge, med Dannebrog frit i Danmarks vang og vænge, vi alle vil virke for vor spejdersag til ære for Danmark, for vort folk og for vort flag«

Konsekvensen af dette stærke engagement $i$ det nationale måtte naturligvis blive, at der ikke var tilstrækkelig tid til den egentlige spejdersport.

I modsætning til bestræbelserne i den sønderjyske hverdag var Det Danske Spejderkorps' ledelse optaget af at forme korpsets arbejde efter de retningslinier, bevægelsens stifter, Robert Baden-Powell havde lagt: et udviklende og karaktertrænende friluftsliv. Et vigtigt skridt i den retning blev taget i 1923, da Ove Holm og Jens Hvass overtalte Lembcke til at forlade posten som spejderchef, og til korpsets ledelse knyttede kendte skolefolk. En anden vigtig interesse var den internationale udvikling. Fra den spæde begyndelse i England i 1907 voksede bevægelsens samlede antal af drengespejdere til i 1930 at udgøre omkring to millioner. Der var spejdere i de fleste lande verden over. I 1924 havde korpset med stor succes gennemført den anden verdensjamboree med deltagelse fra et stort antal lande. Ove Holm var i en længere årrække medlem af bevægelsens internationale komité, og Jens Hvass plejede mange udenlandske kontakter. Visionen var et hele verden omspændende broderskab. "Om Folkenes Forbund danner spejderne æresvagt«, kan man læse $i$ en dengang meget anvendt sang. Men linien var også, at deltagelse i dette internationale samarbejde forudsatte et fast ståsted i det danske.

På baggrund af disse holdninger $\mathrm{i}$ ledende kredse er det let at forstå, at korpset kom til at se kritisk på virksomheden i Aabenraa, hvor man lagde mere vægt på at pleje det nationale end på et aktivt spejderliv, og hvor man, selv om tyske Pfadfindere boede i samme gade, end ikke evnede at pleje samkvem med dem.

Erfaringerne fra Blindebasaren viser, hvor svært det var, ti år efter genforeningen. Man kunne ikke nå så langt, som korpset ønskede, og det kunne næppe heller nogen forlange i år, hvor standpunkterne mellem dansk og tysk i grænselandet var trukket så stærkt op, som tilfældet var. Det første nødvendige var at beskytte sig selv. Idealerne viste sig her, som så ofte før og siden, svære for ikke at sige umulige at omsætte i praksis. Vanskelighederne var for tæt p̊̊. Det bekymrede dog nok korpset mere, at man i Aabenraa forsømte det almindelige spejderarbejde til fordel for udflugter, marcher, parader og 



\section{NOTER}

Baggrundsmaterialet til denne artikel er overvejende hentet i Aabenraa-spejdernes arkiv i Spejderhuset. Det forventes om kort tid afleveret til Landsarkivet i Aabenraa. Spejdernes arkiv omfatter protokoller og dagbøger, foruden korrespondance m.v. Her er enkelte år meget fyldigt repræsenteret, medens der for andre år næsten intet foreligger. Også Kongeå divisionens dagbøger er gennemgået. Hvor andet ikke er anført, stammer alle fotografier fra spejdernes arkiv eller fra Det sønderjyske Spejdermuseum på Stevninghus.

Derudover har mange tidligere Aabenraa-spejdere og andre været mig behjalpelig med detailoplysninger, som jeg takker for. En særlig tak retter jeg til arkivar Lars N. Henningsen for råd og vejledning ved artiklens endelige udformning. Ligeså takker jeg fru Karis Jessen, København for renskrivning af manuskriptet.

1. Artiklen omfatter kun Det Danske Spejderkorps, og ikke de øvrige ungdomskorps. I Aabenraa eksisterede $\mathrm{i}$ alle ăr et nært samarbejde mellem Det Danske Spejderkorps og Det Danske Pigespejderkorps, der udadtil ofte optrădte i fallesskab.

2. En trop består af 1540 spejdere opdelt i 2 - 5 patruljer. En patrulje består af $5-8$ spejdere, hvoraf almindeligvis den ældste er patruljefører.

3. Senere maskinhandler i Logumkloster.

4. Fødtes 1904 i Flensborg, blev relegeret fra Oberrealschule og derfor forhindret i at søge videreuddannelse i Tyskland. Studentereksamen fra Haderslev, cand.theol. i København, hvorefter han fik ansættelse i Dansk Skoleforening for i 1932 at blive lærer, senere skoleinspektør i Slesvig. Har skrevet en erindringsbog: For alt hvad du har kært. Forlaget Skandia. 1978.

5. Rektor Mogensen i Aabenraa Statsskoles Årsskrift 1945.

6. Søn af bankdirektør H. Jørgensen, Den Nordslesvigske Folkebank, uddannet som boghandler. 1991 bosat i Californien.

7. I dag anvendes betegnelsen «leder». Her anvendes den dengang anvendte betegnelse, hvilket også gælder for andre spejderudtryk.

8. Færdigheder og viden, drengen skulle kunne for at blive spejder.

9. Første større prøve efter rekrutprøven, derefter fulgte 1. klasse.

10. En division er en sammenslutning af troppe i et større område eller en større by.

11. En kolonne er en sammenslutning af troppe i et mindre område $f x$. en by og dens opland.

12. Det har ikke kunnet fastslås, hvor artiklen stammer fra, eller hvem pressemanden er.

13. Senere frøhandler, Ramsherred

14. Lektor på Gl. Hellerup Gymnasium

15. Senere skolepedel i Aabenraa

16. Far til Jacob Jacobsen

17. Redaktør, Hejmdal, senere chef for Statsradiofoniens Pressekontor i København.

18. Kaptajn i Grænsegendarmeriet.

19. Tog senere navneforandring til Horsten, kontorchef $i$ Civilforsvarsstyrelsen, medlem af Friluftsrådets bestyrelse, Danmarks Lejrpladsudvalg m.fl.

20. Ordonnanserne var: Mogens Thau, Niels Juul Hansen, Hans Michelsen og Niels la Cour Andersen.

21. Deltager i Hindsgavllejren

22. Repræsentant og handelsmand

23. Et løfte, der skulle aflagges for at blive spejder.

24. Ulvearbejde er et spejderarbejde tilrettelagt for $8-12$ årige på baggrund af Kipling’s »Junglebogen «.

25. Her ligger nu stadion.

26. Tegn på at troppen havde vundet divisionsturneringen.

27. Senere kaldt Skolen bag Rådhuset og Nygades Skole

28. Deltagerne var brødrene Aksel og Harald Uldal, Peter N. Andresen, Holger Oesten, Jens Asby, Mogens Larsen, Tage Fink, Helmuth Hansen, Jørgen Stougaard og Hans Høy. 
29. Ledende personlighed $i$ det danske arbejde.

30. Bornehave i Nygade.

31. Der menes formentlig vandrefugle og andre grupper af unge tyskere.

32. Folketingsmedlem, repræsenterende det tyske mindretal.

33. Ifølge en omfattende rapport fra Simonsen.

34. 3. Aabenraa Trops jubilæumsskrift, duplikeret 1938.

35. Tilskærer ved Magasin (Andersen og Christiansen).

36. Journalist ved Flensborg Avis, fra 1927 - 32 korpschef for Dansk Spejderkorps i Flensborg, senere redaktør i Tønder, april 1940 arresteret af tyskerne, døde kort tid efter i Kastellet i København, 36 år gammel.

37. Aabenraa Statsskoles Årsskrift 1945.

38. De fire var Fritz Hansen, Mogens Larsen, Peter Petersen og Iver Toft.

39. Ulvefører, isenkramkommis, senere fabrikant fabrikken Elto.

40. Forretningsforer.

41. Købmand, Nørreport.

42. Gulvpålægger. 